\title{
GENERATION-SKIPPING TRANSFERS AFTER THE TAX REFORM ACT OF 1976
}

\author{
JOSEPH M. DODGE†
}

\section{INTRODUCTION}

\section{A. Background}

Up until 1976 the federal estate tax did not apply to an interest expiring upon the death of a party ${ }^{1}$ that was created by someone (hereinafter referred to as the "grantor"2) other than the decedent, ${ }^{3}$ even though upon such termination the power or the enjoyment of the property passed to another. ${ }^{4}$ The phenomenon known as a generation-skipping transfer is a transfer from the grantor to the persons owning the interests following that of the expired interest. A trust for the benefit of the grantor's child for life with remainder to the grantor's grandchildren is the prototype of a generation-skipping transfer: upon the child's death nothing was subject to federal estate tax. The theory behind such exclusion is the property-law notion that the interest of the child ("the skipped-generation") does not pass to the successor in interest from him but rather from the grantor. ${ }^{5}$

$\dagger$ Assistant Professor of Law, University of Detroit. B.A. 1963, LL.B. 1967, Harvard University; LL.M. (in taxation) 1973, New York University.

${ }^{1}$ Examples of interests which come within this rule are legal and equitable life estates, remainders contingent on survival, and special powers of appointment.

${ }^{2}$ The term "grantor" is used herein to identify the creator of an interest under both inter vivos and testamentary dispositions. A grantor is also any person adding property to the trust. Of course, the property subject to any interest or power would have been taxed against the grantor or his estate under the gift and estate tax at the time of the transfer which created the interest or power. See I.R.C. $\$ \$ 2033$ (estate tax), 2511 (a) (gift tax).

${ }^{3}$ Where the decedent effected a transfer of property and retained an interest in or a power over the property, the property may be included in his or her gross estate under I.R.C. $\S \S 2036-2040$. Such transfers are not discussed in this article.

${ }^{4}$ E.g., Rev. Rul. 55-438, 1955-2 C.B. 601. An annuity which expires at the decedent's death is not includable in his gross estate regardless of the identity of the purchaser (grantor), since nothing survives the decedent. See C. Lowndes, R. KRaMer, \& J. McCord, Federal Estate and Gift Taxes $\$ 10.2$ (3d ed. 1974) [hereinafter cited as Lowndes et al.].

"The basic estate-inclusion section, I.R.C. $\S 2033$, states: "The value of the gross estate shall include the value of all property to the extent of the interest therein of the decedent at the time of his death." Life estates and powers held by the decedent which 
The only exception to this rule has been for general powers of appointment as defined in section $2041 .^{6}$

In practical terms, therefore, a property owner could avoid tax on the estates of his descendants by the expedient of creating successive beneficial income interests. ${ }^{7}$ The duration of such trusts would be limited only by the Rule Against Perpetuities. ${ }^{8}$ The inconvenience of tying up the property in a trust could be minimized, where desirable or appropriate, by conferring upon the beneficiaries, in addition to an income interest, one or more of the following non-taxable powers and interests: (1) a nontaxable power of disposition of the property; ${ }^{9}$ (2) powers with respect to the trust property which are merely administrative in nature ${ }^{10}$ (3) a right to the corpus limited by an ascertainable fiduciary standard relating to health, education, support or maintenance of the beneficiary; ${ }^{11}$ (4) a non-cumulative right to

were created by the grantor, of course, have a value of zero as of the decedent's death. On the other hand, a vested remainder interest (or a remainder interest which is contingent on events other than the survival of the decedent) is includible in the decedent's gross estate under $\S 2033$ at its value as determined by actuarial principles. Treas. Reg. $\S$ 20.2031-10(d) T.D. 7077, 1970-2 C.B. 183.

${ }^{6}$ I.R.C. \& 2041. The government's attempt to have property subject to a general power of appointment included under I.R.C. $\S 2033$ was rejected by the Supreme Court in Helvering v. Safe Deposit \& Trust Co., 316 U.S. 56 (1942). The theory behind I.R.C. $\$ 2041$ in the case of general powers of appointment by will and by deed are those of unlimited control and constructive ownership respectively. $C f$. Helvering v. Clifford, 309 U.S. 331 (1940) (construing Revenue Act of 1934, § 22(a), 48 Stat. 680); Treas. Reg. $\$$ 1.451-2(a) T.D. 6723, 1964-1 C.B. 74 (constructive receipt of income under I.R.C. $\$ 451$ ).

' Since legal future interests are seldom created today, the discussion here focuses on trust interests. The same tax principles, nevertheless, apply to both. This article does not take any position regarding the issue of whether long-term trusts are inherently undesirable in the economic and social context. See Kinnebrew, Estate and Gift Tax Reform: A Compendium of Thought, 24 Sw. L.J. 608, 624 (1970); Westfall, Revitalizing the Federal Estate and Gift Taxes, 83 HaRv. L. Rev. 986, 1007-08 (1970).

${ }^{8}$ The Rule Against Perpetuities states that for an interest to be valid it must vest, if at all, within lives in being at the time the trust or conveyance becomes fixed plus twenty-one years. J. Gray, Rule Against Perpeturtres § 201 (4th ed. 1942). Also to be considered are the Rule Against the Suspension of the Power of Alienation and the Rule Against Accumulations in states where such variations are in effect. See generally, id., $\S \S 728-752.1$.

9 Namely, a power to dispose of property or create future interests therein in favor of any person other than the decedent or his estate (or the creditors of either). The definition of a general power of appointment in Treas. Reg. $\$ 20.2041-1(c)(1)$ T.D. $6296,1958-2$ I.R.B. 522, describes this exception to the general rule of I.R.C. $\$ 2041$ (a)(2) that property over which the decedent at the time of his death had a general power of appointment is included in the value of his gross estate.

${ }_{10}$ Treas. Reg. $\$ 20.204$ I-1(b)(1) T.D. 6296, 1958-2 I.R.B. 520. Such powers include those of management, investment and custody of assets whereby beneficial interests are not altered except as an incidental result of the discharge of these fiduciary duties. Id.

${ }^{11}$ I.R.C. $\$ 2041(\mathrm{~b})(\mathrm{I})(\mathrm{A})$. 
withdraw the greater of $\$ 5,000$ or five percent of the corpus; ${ }^{12}$ (5) a right to withdraw corpus held jointly with a party having a substantial adverse interest in the property subject to the power; ${ }^{13}$ and (6) the possibility of receiving corpus pursuant to the trustee's exercise of his discretion. ${ }^{14}$

The Treasury and commentators from time to time had questioned this state of affairs on several grounds. ${ }^{15}$ First, the cumulative interests and powers capable of being conferred on the beneficiary without incurring estate tax liability in some cases virtually amount to absolute ownership. ${ }^{16}$ Second, an income interest in itself is substantial both in a property and economic sense. ${ }^{17}$ Third, inequity results among differing patterns of wealth disposition. For example, a grandchild remainderman under a trust for his parent would have his interest reduced by only the grantor's federal estate tax; his generational counterpart receiving property acquired outright by his or her parent, however, would receive such property after it has passed through the estate tax wringer at least twice. ${ }^{18}$ Perhaps another

12 I.R.C. $\$ 204$ l(b)(2). A non-cumulative power is one that lapses periodically. The typical situation would be a right to withdraw a certain amount of corpus annually. However, in the year of death, the power would not have lapsed and therefore the amount that is subject to the power would be includible in the beneficiary's gross estate. Treas. Reg. $\S 20.2041-3(d)(3)$ T.D. 6296, 1958-2 I.R.B. 530. Even this tax risk can be reduced by providing in the trust, for example, that the power will not come into existence until December 26 of each year, thereby minimizing the possibility that the beneficiary will die during the period when such power exists.

${ }^{13}$ I.R.C. \& 2041(b)(1)(C)(ii). A person having a substantial adverse interest to that of the decedent would include an income or corpus beneficiary. See Treas. Reg. $\S 1.672(\mathrm{a})-1$ (1960).

${ }^{14}$ Rev. Rul. 76-368, 1976-39 I.R.B. 9. This possibility does not rise to the status of a power or interest because it is not legally or equitably enforceable.

${ }^{15}$ See G. Jantscher, Trusts and Estate Taxation, 162-66 (1967); U.S. Treasury Dep't, Tax Reform Studies and Proposals, pt. 3 (Joint Publication of House Comm. on Ways \& Means and Sen. Comm. on Finance, 9lst Cong., 1st Sess. 1969) [hereinafter cited as 1969 Treasury Proposals], reprinted in Staff of House Comm. on Ways and Means, 94th Cong., 2D Sess., Background Materials on Federal Estate and Gift Taxation 183-309 (Comm. Print 1976) [hereinafter cited as 1976 Background Materials]; Dodge, Substantial Ownership and Substance Versus Form: Proposals for the Unification of Federal Estate and Gift Taxes and for the Taxation of Generation-Skipping Transfers, 1976 U. ILl. L.F. 657 (1976); Kurtz \& Surrey, Reform of Death and Gift Taxes: The 1969 Treasury Proposals, The Criticisms and a Rebuttal, 70 Colum. L. Rev. 1365, 1391-92 (1970); Mills, Transfers from Life Tenant to Remainderman, 19 TAXes 195 (1941).

The British have traditionally taxed the expiration of life estates, although the technique has changed from time to time. Finance Act, 1894, 57 \& 58 Vict. 53, c. 30 , $\S \S 1-2$, as amended; Finance Act, 1969, c. 32, §\$ 36-37; Capital Transfer Tax Act, 1975.

${ }^{16}$ See Dodge, supra note 15 , at 662-67.

${ }^{17}$ See G. JANTSCHER, supra note 15, at 164-65.

${ }^{18} 1969$ TrEasury Proposals, supra note 15 , at 388. The same, of course, can be said for an outright gift to the grandchild. Such a gift, however, is in a substantially 
way of making the same point is to state that the federal transfer taxes should be imposed upon wealth at reasonably frequent intervals. ${ }^{19}$ Fourth, the "neutrality" principle is violated insofar as tax factors unduly influence a grantor's selection in favor of creating long-term trusts. Finally, and perhaps most politically damaging, only families with substantial wealth can afford to take advantage of long-term trusts, because only they can anticipate that a substantial portion of the capital would be preserved. ${ }^{20}$

\section{B. Overview of the 1976 Reform}

In the Tax Reform Act of 1976 Congress, with undue haste, responded to the loophole of generation-skipping transfers by adding chapter 13 to the Internal Revenue Code. ${ }^{21}$ Chapter 13

different category of transfers, because the child derives no enjoyment from the property given to the grandchild.

${ }^{19}$ See Sen. Comm. on Finance Supplemental Report on Additional Comm. Amendment to H.R. 10612, S. Rep. No. 94-938, pt. 2, 94th Cong., 2d Sess. 19 (1976) [hereinafter cited as SENATE REPORT]. This idea is referred to as the "periodicity" notion, and has no necessary relation either to the notion of generation-skipping or to that of the shifting of current enjoyment of property.

${ }^{20}$ SeNate RePORT, supra note 19, at 20.

${ }^{21}$ Tax Reform Act of 1976, Pub. L. No. 94-455, § 2006, 90 Stat. 1879-90, adding I.R.C. $\$ \S 2601-2603,2611-2614,2621-2622$ [hereinafter cited as the Tax Reform Act of 1976, or simply as the Act]. Chapter 13 also amends I.R.C. $\$ \$ 303,691$ (c), \& 2013. Citations are made to the Code sections rather than to the Act sections, except where indicated. The estate and gift tax reform package first appeared as a separate bill as recently as May 24, 1976. H.R. 13966, 94th Cong., 2d Sess., 122 Cong. REc. H4846-49 (daily ed. May 24, 1976). To be sure, hearings had been held in the House Ways and Means Committee from March 15 through March 23, 1976, as well as in 1973. See Staff of House Comm. on Ways and Means, 94th Cong., 2d Sess., Public Hearings And Panel Discussions On Federal Estate And Gift Taxes Before House Ways and Means Comm. (Comm. Print 1976); Staff of House Comm. on Ways and Means, 93D Cong., 1st Sess., Panel Discussions On General Tax Reform Before House Comm. ON Ways and Means, pt. 10 (Comm. Print 1973). See also Hearings on Tax Reform Act of 1969 Before House Comm. on Ways and Means, 91st Cong., 1st Sess., pt. 11 (1969). The 1976 hearings, however, primarily focused on the Ford Administration proposals for higher estate and gift tax exemptions, expanded estate and gift tax marital deductions, and provisions relating to farm property and small business property. See Hearings Before House Ways and Means Comm., 94th Cong., 2d Sess. (1976) (Statement of Treasury Secretary Simon). The 1976 Estate and Gift Tax Reform Bill, H.R. 14844, 94th Cong., 2d Sess., 122 Cong. Rec. 7758 (daily ed. July 26, 1976), as reported out of the House Ways and Means Committee in late July of 1976 contained (in addition to generation-skipping rules) provisions for the unification of estate and gift taxes and a carry-over basis provision for property acquired from a decedent. H.R. REP. No. 94-1380, 94th Cong., 2d Sess., reprinted in [1976] U.S. Code Cong. \& Ad. News 460 [hereinafter cited as HouSE REPORT]. The generation-skipping provisions of this bill were not modelled closely after any of the proposals previously submitted to the committee. See Staff of House Comm. on Ways and Means, 94th Cong., 1st Sess., Public Hearings on General Tax Reform Before House Comm. on Ways and Means, pt. 9, 
imposes a tax (hereinafter referred to as the "generationskipping tax") upon any "generation-skipping transfer" occurring in the context of a "generation-skipping trust" or "trust equivalent." ${ }^{22}$ Specifically, a generation-skipping transfer occurs (a) upon a "taxable termination" of an "interest" or "power" of a "beneficiary" who belongs to a "generation" below that of the grantor but above that of another beneficiary (or remainderman) or (b) upon a "taxable distribution" to a beneficiary where there exists a beneficiary who belongs in a generation between those of the grantor and of the distributee. ${ }^{23}$ Thus, in the pro-

at 4070-77 (Comm. print 1973) (American Bankers Association's Discussion Draft of Transfer Tax Statute and Explanatory Comments), reprinted in 1976 BACKGRouND Materials, supra note 15, at 429-641; American Institute of Certified Public Accountants, Estate and Gift Tax Reform (1976), reprinted in 1976 Background Materials, supra note 15, at 643-711; American Law Institute, Federal EsTate and Gift Taxation: Recommendations and Reporters' Studies (1969), reprinted in part in 1976 BACKGROUND MATERIALS, supra note 15, at 311-79; G. JANTSCHER, supra note 15, at 162-90; 1969 Treasury Proposals, supra note 15, at 393-401. (Of these, perhaps the American Bankers Association proposal bears the greatest resemblance to H.R. 14844.) Shortly thereafter, on August 6, 1976, and although the House had not passed H.R. 14844 , the Senate passed the general income tax reform package which it was then considering after adding its own estate and gift tax reform provisions. H.R. 10612, $\$ \$ 2201$ (a), (b), 2202, 94th Cong., 2d Sess., 122 Cong. Rec. \$13797 (daily ed. Aug. 6, 1976). See Senate Report, supra note 19, at 13-14, 19-21. Virtually no hearings were held by the Senate Finance Committee on the estate and gift tax reform provisions, and in any event the time available was certainly insufficient for interested parties to analyze and criticize them. The House never passed H.R. 14844 as such; the bill was withdrawn from the floor by Rep. Al Ullman, Chairman of the House Ways and Means Committee, on August 30, 1976, following an open-rule vote permitting amendments from the floor, 122 CoNg. Rec. H9220-21 (daily ed. Aug. 30, 1976). Nevertheless, the provisions of H.R. 14844, with modifications, were addended to the general tax reform bill (H.R. 10612) by the Conference Committee in its last day of deliberations. H.R. REP. No. 94-1515, 94th Cong., 2d Sess. 614, reprinted in [1976] U.S. Code Cong. \& AD. News 1222,1356 (joint explanatory statement of conference committee) [hereinafter cited as CoNfERENCE RePORT]. H.R. 10612, as amended to include the estate and gift tax reform package, was passed by the full Congress in September, 122 Cong. ReC: H 10275 (daily ed. Sept. 16, 1976) (House passage), 122 Cong. Rec. S16028 (daily ed. Sept. 16, 1976) (Senate passage), and signed by President Ford on October 4, 1976, 122 Cong. Rec. H 12425 (daily ed. Oct. 26, 1976).

Because the new provisions were not modelled on prior proposals, and because of the hasty fashion in which they were rushed through Congress, the only direct authority for statements in this article about the new provisions are the text of the bill itself and the various committee reports. House RePORT, supra; SENATE REPORT, supra note 19; CONFERENCE REPORT, supra.

${ }^{22}$ I.R.C. $\$ \S 2601,2611(\mathrm{a})$-(b).

${ }^{23}$ I.R.C. $\$ \$ 2613$ reads in pertinent part as follows:

(a) ... For purposes of this chapter-

(1) ... The term "taxable distribution" means any distribution which is not out of the income of the trust . . . from a generation-skipping trust to any younger generation beneficiary who is assigned to a generation younger than the generation assignment of any other person who is a younger generation beneficiary. For purposes of the preceding sentence, an individual who at no time 
totypical case of a trust created by the grantor for his child for life, remainder to his grandchild, a generation-skipping transfer in the form of a taxable termination occurs within the meaning of the statute when the child dies. ${ }^{24}$ If the trustee makes a distribution out of the corpus to the grandchild, a taxable distribution occurs because there would be one younger generation beneficiary (the child) who is a member of a generation older than that of the grandchild. In the case of a taxable termination, the tax base is computed with reference to the value of the corpus of the trust on the date of termination, ${ }^{25}$ and the trust property bears the burden of the tax. ${ }^{26}$ In the case of a distribution, the tax base is computed with reference to the amount of the distribution, ${ }^{27}$ and the tax is borne by the distributee. ${ }^{28}$ The tax is computed under the new unified transfer tax rate table, ${ }^{29}$ by

has had anything other than a future interest or future power (or both) in the trust shall not be considered as a younger generation beneficiary. . . .

(b) ... For purposes of this chapter-

(1) ... The term "taxable termination" means the termination (by death, lapse of time, exercise or nonexercise, or otherwise) of the interest or power in a generation-skipping trust of any younger generation beneficiary who is assigned to any generation older than the generation assignment of any other person who is a younger generation beneficiary of that trust. Such term does not include a termination of the interest or power of any person who at no time has had anything other than a future interest or future power (or both) in the trust.

A "higher" or "older" generation (with respect to descendants of the grantor) is one that is closer to the grantor, such as a child, than is a "lower" or "younger" generation beneficiary, such as a great-grandchild.

${ }^{24}$ The child and grandchild are in two different generations below that of the grantor. The death of the child constitutes the termination of an interest (the life estate) in the context of the generation-skipping trust. Although there would also be a "distribution" upon the termination of the trust, the rules pertaining to terminations control if an event gives rise to both a termination and a distribution. I.R.C. $\$ 2613$ (b)(7)(A).

${ }^{25}$ I.R.C. § 2602(a)(1)(A).

${ }^{26}$ I.R.C. $\$ 2603(\mathrm{a})(1)(\mathrm{A})$.

27 I.R.C. $\$ 2602(a)(1)(A)$.

${ }^{28}$ I.R.C. $\$ 2603(\mathrm{a})(\mathrm{l})(\mathrm{B})$.

${ }^{29}$ I.R.C. $\$ \S 2602(a)(1), 2001(c)$. Under the law as it existed prior to the Tax Reform Act of 1976, taxable gifts were taxed under a separate rate and exemption schedule than that for the taxable estate. Compare I.R.C. $\$ 2001$ (1954) (estate tax) with I.R.C. $\$ 2502$ (1970) (gift tax). Pursuant to I.R.C. $\S 2001$, effective after Dec. 31, 1976, the amount of adjusted taxable gifts becomes part of the decedent's estate tax base. I.R.C. $\$ 2001$ (b) provides that:

The tax imposed ... shall be the amount equal to the excess (if any) of ... a tentative tax computed in accordance with the rate schedule set forth in subsection (c) on the sum of ... the amount of the taxable estate, and . . the amount of the adjusted taxable gifts, over . . the aggregate amount of tax payable under chapter 12 [the gift tax provisions] with respect to gifts made by 
treating the generation-skipping transfer tax base as if it were a taxable gift or a "second" estate of the "deemed transferor." The deemed transferor is generally the parent of the transferee who is more closely related to the grantor. ${ }^{30}$ There is an exclusion from the tax base of up to $\$ 250,000$ for each child of the grantor who is a deemed transferor with respect to transfers to the grantor's grandchildren. ${ }^{31}$ Additionally, the new rules are integrated to a large extent with the federal unified transfer and income taxes. ${ }^{32}$

The new generation-skipping tax provisions contain serious conceptual problems, predominantly concerning the concept of the deemed transferor. ${ }^{33}$ Of more immediate concern to practitioners are various ambiguities and technical difficulties presented by the statute. Although many of these problems will eventually be resolved through the issuance of regulations within the Treasury Department's broad authority, ${ }^{34}$ the regulatory solution will not provide any help in the short run. The purpose of the discussion which follows is to explain the details of the provisions, point out the major problems, suggest solutions, and indicate some planning considerations.

\section{Generation-SkipPing Trust}

\section{A. Assignment of Generations}

A termination or distribution does not give rise to the tax unless it occurs with respect to a generation-skipping trust. ${ }^{35}$ As previously intimated, the latter presupposes the existence of younger generation beneficiaries who occupy at least two differ-

the decedent after December 31, 1976.

The resulting tax is reduced by the available unified transfer tax credit, which will be by 1981 the equivalent of a specific exemption of about $\$ 175,000$. I.R.C. $\$ \S 2001,2010$, $2101,2502(a), 2505$. The federal gift tax is computed in essentially the same manner as before except that the unified credit replaces the $\$ 30,000$ lifetime exemption of repealed I.R.C. $\$ 2521$ (1970), for post-1976 gifts. The federal estate tax is now computed in the same manner as the gift tax, except that the unified transfer tax credit has replaced the $\$ 60,000$ specific exemption of repealed I.R.C. $\$ 2052$ (1954), for those dying after 1976. The doctrine distinguishing a taxable gift from an item to be included in the gross estate is substantially unchanged.

${ }^{30}$ I.R.C. $\S 2612(a)$.

${ }^{31}$ I.R.C. $\S 2613(b)(6)$.

${ }^{32}$ See, e.g., I.R.C. $\$ \$ 2602(c)-(e), 2614(a)-(b), 2621$.

${ }^{33}$ See text accompanying notes 96-141 infra.

${ }^{34}$ See I.R.C. \$§ 2613(b)(2)-(3), 2621(c), 2622. See generally I.R.C. \$ 7805.

${ }^{35}$ I.R.C. $\$ 2611$ (a). See text accompanying note 22 supra. 
ent generations. ${ }^{36}$ Thus, a trust for the benefit of the grantor's sister for life with remainder to the grantor's grandchild lacks the requisite two generations below that of the grantor. Similarly, a trust for one grandchild of the grantor for life, remainder to another grandchild, does not fall within the definition of the Act because although there exist two younger-generation beneficiaries they occupy the same generation.

The placement of a person in a generation presents no problem where lineal descendants of the grantor are concerned. Placement of collateral relatives of the grantor is more complicated. For lineal descendants of a grantor's grandparent, generations are fixed by comparing the number of generations between that grandparent and the descendant with the number of generations between that grandparent and the grantor. ${ }^{37}$ A spouse of the grantor or a beneficiary is always deemed to be of that generation. ${ }^{38}$ This is so regardless of the age of the spouse. Hence, somewhat ironically, a trust to provide support for the grantor's wife, who is thirty years younger than the grantor, remainder to issue, is not a generation-skipping trust. For all persons not assigned to a generation by the foregoing rules, generations are tolled at twenty-five year intervals. Persons born not more than twelve and a half years after the grantor's birthdate are assigned to his generation; those born more than twelve and a half years but not more than thirtyseven and a half years after the grantor's birthdate are assigned to the next younger generation, and so forth. ${ }^{39}$ Therefore, under this rule two persons who are biologically of different generations can be treated, albeit illogically, as belonging to the same generation. ${ }^{40}$

${ }^{36}$ I.R.C. $\$ 2611$ (b). See note 24 supra.

${ }^{37}$ I.R.C. $\$ 2611$ (c)(1).

${ }^{38}$ I.R.C. $\S 2611(c)(2)$. A former as well as a present spouse of the grantor is considered to be in the same generation as the grantor. See SENATE REPORT, supra note 19, at 21. Relationships by adoption and half-blood are treated as relationships of the whole blood. I.R.C. $\S \S 2611$ (c)(3)-(4), 2613(f). Finally, a person who falls into more than one generation is assigned to the youngest one. I.R.C. $\$ 2611$ (c)(6).

${ }^{39}$ I.R.C. $\$ 2611(\mathrm{c})(5)$. This rule would apply to non-relatives of the grantor and to collateral relatives whose common ancestor is further removed than the grantor's grandparent.

to For example, assume that the grantor's second cousin is 13 years younger than the grantor, and the cousin's son is 35 years younger than the grantor; under these rules both individuals are considered to be in the same generation. It would have been better to provide that once a beneficiary is assigned a generation with respect to the grantor, the generation assignment of his ancestors and descendants would be determined with reference to him and not to the grantor. 
It should be pointed out that there is a fundamental incongruity in the basic scheme. If the problem is defined as tax avoidance by one who enjoyed the property, then a tax should be imposed upon a termination or distribution regardless of the generation-assignment of the beneficiary. If the problem is viewed as the skipping of generations per se, then outright transfers, to grandchildren, for example, should be taxed. But the new provisions do not take this step, and for good reason. Taxing donees of outright gifts and bequests would discriminate against them solely because of their generational status. ${ }^{41}$

\section{B. Definition of Terms}

\section{Beneficiary}

The term "beneficiary" obviously includes one who possesses a legal or equitable life estate. The statute goes further and expansively defines a beneficiary as a person who possesses any present or future "power" or "interest" in the trust. ${ }^{42}$

\section{Power}

The term power is defined to include "any power to establish or alter beneficial enjoyment of the corpus or income of the trust." ${ }^{43}$ This definition overlaps with that of a general power of appointment whose possession causes estate tax exposure under Internal Revenue Code section 2041 in its coverage of a power to appoint corpus to the decedent, his estate, or the creditors of either. ${ }^{44}$ Section 2041 prevails over the generation-skipping rules to the extent of the overlap. ${ }^{45}$ Nevertheless, the generationskipping definition of power clearly covers certain powers expressly excluded from the reach of section 2041; these are a power to invade corpus limited by an ascertainable standard re-

${ }^{11}$ Moreover, there is no social or economic reason why such transfers should be penalized. Any benefit derived by the skipped generation in the case of outright transfers is speculative at best.

42 I.R.C. $\$ 2613(\mathrm{c})(3)$. A corporate trustee can be a beneficiary because a "person" as defined in I.R.C. $\$ 7701(a)(1)$ includes a corporation, but cannot be a younger generation beneficiary, because a corporate trustee cannot be assigned to a generation. Nor can a corporate trustee be involved in a generation-skipping transfer, because the latter requires either the termination of an interest of, or the distribution to, a younger generation beneficiary. See text accompanying notes 22-23 supra.

${ }^{43}$ I.R.C. $\$ 2613$ (d)(2). This definition is reminiscent of I.R.C. $\$ \$ 2036(a)(2), 2038$, which apply to powers retained by the grantor over income and corpus respectively.

$\$ 4$ I.R.C. $\$ 2041(b)(1)$.

${ }^{45}$ I.R.C. $\$ \S 2613(\mathrm{a})(4)(\mathrm{B}),(\mathrm{b})(5)(\mathrm{B})$. 
lating to health, education, support or maintenance, ${ }^{46}$ and a non-cumulative power to invade corpus to the extent of $\$ 5,000$ or five percent of the value of the corpus per year. ${ }^{47}$ The estate tax consequences under section 2041 with respect to a general power only over income was not made entirely clear. It is likely, however, that inclusion will result, at least to some extent, under one of a variety of theories. ${ }^{48}$ Such a power would clearly be included under the generation-skipping provisions.

It is important to note that powers exercisable exclusively for the benefit of lineal descendants of the grantor of the trust who belong to generations below that of the power holder are excluded under the generation-skipping provisions. ${ }^{49}$ Thus, where the grantor creates a trust for the benefit of his grandchildren for a specified period, with remainder over, and names the grantor's son as trustee, the generation-skipping tax does not apply upon the death of the son. ${ }^{50}$ Since this is a common form of special power of appointment, the exception has the potential to effectively swallow up the general rule. ${ }^{51}$ The exception, therefore, will tend to undermine the neutrality principle. If a revised transfer tax scheme taxes granted as well as retained interests, retained powers, and granted general powers of appointment, then special powers of appointment should be taxed to complete the coverage. Moreover, a special power exercisable

${ }^{46}$ 1.R.C. $\$ 2041$ (b)(1)(A). See text accompanying note 11 supra.

${ }^{47}$ I.R.C. $\$ 2041$ (b)(2). See text accompanying note 12 supra. For purposes of the generation-skipping rules, a "five-and-five" power, as well as one limited by ascertainable standards, is to be regarded as a power over the entire corpus, not just a portion thereof, on the theory that the entire corpus could be consumed given sufficient time. CONFERENCE RePORT, supra note 21 , at 618 n.1. See also note 54 infra \& accompanying text.

${ }^{48}$ The amount to be included in such a case would be the accumulated income in the trust that has in the past been subject to the power, the current year's income subject to the power, and any income accumulated with respect to either of the foregoing. The debate centers over whether the "five-and-five" exclusion of I.R.C. \$ 2041 (b)(2) applies to any such non-cumulative power over income. Compare Fish v. United States, 432 F.2d 1278, 1281 (9th Cir. 1970) (allowing an exemption of $\$ 5,000$ under $\S 2041(\mathrm{~b})(2)$ with respect to a power of appointment over trust income) with Horner v. United States, 485 F.2d 596 (Ct. Cl. 1973) (ignoring $\S 204$ l's exclusion provisions with respect to a similar power of appointment).

${ }^{49}$ I.R.C. $\$ 2613(\mathrm{e})$. The definition of power is therefore substantially the same as that in effect from 1942 to 1951 . Revenue Act of 1942, § 403, 56 Stat. 798, 942.

5" The son is not a "beneficiary." The generation-skipping tax may apply upon the expiration of the interests of the grandchildren, if the remainder is to a still younger generation.

51 The exclusion would presumably be lost if, in addition to the grandchildren, the grantor's parents or spouse, or the son's spouse were designated as potential beneficiaries of the son's power because they would not be in a younger generation than the son. 
in favor of one's issue is the most valuable of such powers and it is difficult to distinguish it on practical grounds from a general power of appointment. ${ }^{52}$

Some significant ambiguities also exist in the definition of power under the new rules. For example, it is not clear whether a power exercisable in favor of others which is limited by a fiduciary standard is within the scope of the new rules. ${ }^{53}$ The status of jointly-held powers ${ }^{54}$ is similarly uncertain..$^{55}$ However, unlike the provisions of section 2041, the result here would probably not hinge on whether the co-holder possesses a substantial adverse interest. ${ }^{56}$ Finally, a power to terminate the trust without altering the identities or shares of beneficiaries is not expressly covered by the statute. ${ }^{57}$ In each of these instances there is no clue in the text or legislative history as to the intended result. Given the ambiguities in and exclusions from the definition of power in sections 2613(d) and (e), it may have been better if Congress had left the area untouched.

\section{Interest}

The term "interest" is defined as "a right to receive income or corpus from the trust." 58 This definition includes legal and equitable life estates and terms for years, and that which is not a

${ }^{52}$ See Dodge, supra note 15 , at 678-79 n.110, \& 685-86 n.145.

${ }^{53}$ The exclusion for managerial powers, House REPORT, supra note 21 , at 47, 49, strongly implies that discretionary powers limited by fiduciary standards would come within the definition of power. Such a result would differ, however, from that under I.R.C. $\$ \$ 2036(a)(2) \& 2038$ for retained powers, upon which the phrasing of I.R.C. $\$ 2613(\mathrm{~d})(2)$ is substantially based. See Lowndes et al., supra note 4, at $\$ 8.9$.

54 Under I.R.C. $\$ 2041(\mathrm{~b})(1)(\mathrm{C})(\mathrm{ii})$, a joint power is not deemed to be a general power of appointment where the co-holder has a substantial interest adverse to exercise of the power in favor of the decedent. See note 13 supra. (The grantor of the power has the same status as an adverse party under I.R.C. $\$ 2041$ (b)(l)(C)(i).) The existence of a co-holder who is a potential appointee under the power, but who will not succeed to the power, and not otherwise having a substantial adverse interest, will cause the decedent's estate to be taxed only on a pro rata portion of the property. See Treas. Reg. $\S 20.2041-3(c)(2)$ T.D. $6296,1958-2$ I.R.B. 528.

${ }^{55}$ Unlike the provision here, I.R.C. $\$ \$ 678,2041(b)(1)(C)$ explicitly state the significance of the presence or absence of a co-holder of a power. I.R.C. $\$ \S 2036$ (a)(2), 2038 also specifically include the property in a grantor-decedent's gross estate where he retained the power jointly with another party.

${ }^{56}$ I.R.C. $\$ \S 2613(d)(2) \&$ (e) make no reference to the definition of power in $\S 2041$, and it is not expected that courts would treat $\$ 2041$ as a gloss on $\$ 2613$. Bul cf. Camp v. Commissioner, 195 F.2d 999 (1st Cir. 1952) (construing Rev. Act of 1932, $\S 501,47$ Stat. 245) (Gift Tax).

${ }^{57} \mathrm{Cf}$. Lober v. United States, 346 U.S. 335 (1953) (construing Int. Rev. Code of $1939, \S 811(d)(2), 53$ Stat. 121 (now I.R.C. $\S 2038(a)(2))$ ). Such a power is expressly placed in the taxable category under I.R.C. $\S 2038(a)(1)$.

${ }^{58}$ I.R.C. $\S 2613(d)(1)(A)$. 
"right" under present section 2036(a)(1) ${ }^{59}$ but is the mere possibility of receiving income or corpus under a power exercisable by another. ${ }^{60}$ Hence, beneficiaries of a discretionary or sprinkle trust possess interests, as do contingent remaindermen, potential distributees, and possible appointees. A person, including a remainderman, who actually receives property pursuant to the trust, or is vested with an interest therein is a fortiori included within the definition. ${ }^{61}$

This broad definition of interest somewhat reduces the significance of the exclusions and ambiguities involved in the definition of power, since virtually any power that might be excluded from the new rules presupposes the existence of a terminable interest in the beneficiary who will or might benefit from the existence or exercise of the non-taxable power. ${ }^{62}$ In addition, existing rules will preempt the generation-skipping rules where both apply to the same factual situation. ${ }^{63}$

${ }^{59}$ In the case where the grantor is also a beneficiary of the trust, the value thereof would be includible under 1.R.C. $\$ 2036$ only where he retains the possession or enjoyment of the property or the right to the income therefrom. The term "right" had been construed to primarily cover situations where the grantor-beneficiary could compel the trustee, under the terms of the trust instrument or local law, to pay him the income of the trust. See Lowndes et al., supra note 4, at \$§ 9.12-.14. A retained power to obtain corpus from the trust in a similar situation is covered by I.R.C. $\$ 2037$ rather than $\S$ 2036. Compare Estate of Arthur Klauber, 34 T.C. 968 (1960), zwith Estate of May Valentine, 54 T.C. 200 (1970).

6" I.R.C. $\S 2613(\mathrm{~d})(\mathrm{l})(\mathrm{B})$ provides that a person has an interest in a trust if such person "is a permissible recipient of . . income or corpus."

${ }^{61}$ See House Report, supra note 2I, at 48-49. A person does not possess an interest, however, where the trustee is directed to accumulate income during the person's life, unless such income is payable to his estate, in which case I.R.C. $\S 2033$ appplies.

${ }_{62}$ See House RePORT, supra note 21, at 49. For example, assume the grantor creates a trust with his child as trustee, giving the child the power to distribute income from time to time and/or corpus to the child's surviving issue. Upon the death of the childtrustee, the trust is to terminate and the corpus is to be distributed to the grantor's issue per stirpes. In this example, the power held by the child-trustee is exempt under I.R.C. \$ 2613(e). See text accompanying note 49 supra. Nevertheless, upon the child-trustee's death, the interests of the various beneficiaries will then terminate in a taxable transfer, assuming that lower-generation beneficiaries (remaindermen) exist at that time. The point is that even if the death of the holder of a power does not give rise to tax liability, eventually a taxable termination of interests will occur.

${ }^{63}$ For a discussion of preemption by I.R.C. $\$ 2041$, see notes $45-48$ supra \& accompanying text. An instance in which I.R.C. $\& 2033$ would preempt the generationskipping rules is a trust created by the grantor for his child for life, then for his grandchild until the age of 21 , at which time the corpus is to be distributed to the grandchild, but if the grandchild dies prior to attaining the age of 21 , then to the grandchild's estate. If the grandchild dies before attaining the age of 21 , there would be a taxable termination if his successors in interest are lower-generation beneficiaries. However, the interest of the grandchild would be included in his gross estate under $\$ 2033$ in any 
Although interests properly outweigh powers in importance, the definition of interest in section $2613(d)(1)$ is not without its own inherent difficulty, namely the inclusion of mere possibilities of receiving income or corpus under discretionary powers. Of course, unless discretionary trusts are reached, the entire scheme would be weakened by a loophole. The appropriate approach, however, would have been to tax beneficial interests under discretionary trusts according to the actual enjoyment of beneficiaries instead of what they might have received. ${ }^{64}$

\section{Trust Equivalent}

The generation-skipping trust concept also encompasses a generation-skipping "trust equivalent." 65 This term includes, but is not limited to, legal life estates, annuities, life insurance and other death benefits, and split-interests in general. ${ }^{66}$ It is clear that more than one such interest, even if legally or contractually discrete, can be combined in order to produce a generationskipping trust equivalent. ${ }^{67}$ The statute, however, provides no clues to determine under what circumstances such an equivalent would be deemed to exist. Hopefully, the drafters of the regulations will provide guidelines that will resolve this issue. ${ }^{68}$

event, and it is therefore unnecessary to determine whether the generation-skipping rules would in fact apply to the termination.

${ }^{64}$ The beneficiary would be deemed to have enjoyed a portion of the trust in the same ratio to the total trust as the trust accounting income received by him bears to total trust accounting income. This suggestion raises technical problems relating to (1) the period over which such income is measured, (2) the definition of trust accounting income, (3) the treatment of corpus distributions, and (4) the status of accumulations. For proposed solutions, see Dodge, supra note 15, at 670-78.

${ }_{65}$ I.R.C. $\$ 2611(\mathrm{~d})(1)$.

${ }^{66}$ I.R.C. $\$ 2611(\mathrm{~d})(2)$.

${ }^{67}$ I.R.C. $\$ 2611$ (d) is reminiscent of I.R.C. $\$ 2039$ (a), which was enacted in part to overrule cases preventing imposition of the estate tax upon separate annuity and insurance contracts under pre-1954 law. Compare Fidelity-Philadelphia Trust Co. v. Smith, 356 U.S. 274 (1958) (pre-1954 law), with Estate of Lafayette Montgomery, 56 T.C. 489 (1971), aff'd, 458 F.2d 616 (5th Cir.), cert. denied, 409 U.S. 849 (1972) (result under $\S 2039$ ).

${ }^{68}$ The various committee reports offer no assistance. See House REPORT, supra note 21, at 47 n.l. Aside from the "contract" principles embodied in I.R.C. $\$ 2039$ (a), it is conceivable that split-interest arrangements could be combined with reference to the time of creation, the relationship of persons creating the interests, the motives of the grantors, or the manner in which the interests fit together from an objective viewpoint. Cf. United States v. Estate of Grace, 395 U.S. 316, 324 (1969) (construing Int. Rev. Code of 1939, $\$ 811(\mathrm{c})(1)(B), 63$ Stat. 894 (now I.R.C. $\$ 2036)$ ). Because new Code provisions have been enacted, the Treasury could probably establish fairly broad ground rules in this area by means of regulation. See I.R.C. $§ 2622$. 


\section{Generation-SkipPing Transfer}

\section{A. Taxable Termination}

A generation-skipping transfer is subject to tax if it is a taxable termination or a taxable distribution with respect to a generation-skipping trust or trust equivalent. ${ }^{69} \mathrm{~A}$ "taxable termination" refers to the expiration (usually by reason of death, the passage of a period of years, or the occurrence of a contingency) of an interest or power of a younger generation beneficiary where there exists at least one beneficiary of an even younger generation. ${ }^{70}$ The existence of the requisite two beneficiaries each of a different younger generation is apparently determined at the moment immediately prior to the termination, as opposed to the time when the trust was "created, though this point could have been expressed more clearly in the statute. ${ }^{71}$

${ }^{69}$ I.R.C. $\$ 261$ l(a). See text accompanying note 22 supra.

7" I.R.C. $\S 2613(b)(1)$. In the prototypical example of a transfer in trust by the grantor for the benefit of his child for life, remainder to his grandchild, there is, prior to the termination of the interest of the child, a future beneficiary who is of a younger generation than the present beneficiary. Where a reversion in the grantor's estate is retained, or where the remainder is ambiguous (for example, "to issue"), the persons in existence at the time of the termination who will take the remainder interest must be identified. For example, if a reversion to the grantor's estate follows a life estate in grantor's child, no generation-skipping transfer would be deemed to occur if the grantor's successors in interest are persons who belong exclusively to the same generation as the child who was the beneficiary.

${ }^{71}$ I.R.C. $\S 2613(c)(2)$. The example given in the House Report, supra note 21 , at 50 $\mathrm{n} .3$, is not very helpful. It posits a trust providing for income to the grantor's child for life, then to charity for 10 years, with remainder to the grantor's great-grandchild, and draws the obvious conclusion that a generation-skipping transfer occurs upon the death of the child. A subsequent example given in the House Report, supra note 21 , at 53 \& $\mathrm{n} .9$, to explain other provisions discussed subsequently, note 134 infra \& accompanying text, unnecessarily confuses the issue. There, the grantor creates a trust for his son for life, then to great-grandchild $A$ for life, then to the son's uncle (grantor's brother) for life, with the remainder to be distributed to the grantor's great-grandchild $B$. It is implied in the example that the death of the grantor's brother would be a taxable termination. In reality, as of the death of the grantor's brother, assuming that the grantor's son and great-grandchild $A$ predeceased the grantor's brother in proper order, there would not exist the requisite two generations of younger-generation beneficiaries, since the grantor's brother is not a younger-generation beneficiary within the meaning of I.R.C. $\S 2613(\mathrm{c})(1)$. (The termination of the son's interest would clearly have been a generation-skipping transfer.) It might appear that a transfer in this form would be a tax-avoidance device. However, that follows from the basic principles of chapter 13. Since a trust created by a grantor simply for his brother for life with remainder to the grantor's grandchildren would clearly not give rise to a generation-skipping transfer upon the brother's death, the result should not be changed by the insertion of precedent interests. Supporting the foregoing interpretation is the wording of I.R.C. $\S$ 2613(b)(2)(C)(ii)(II), as applied to a trust for the grantor's son for life, then to the grantor's spouse, remainder to the grantor's grandchild. If the child dies first, the tax with respect to him is postponed until the death of the grantor's spouse. See text accom- 
The assignment of an interest or power (whether for consideration or not) does not constitute a taxable termination. ${ }^{\mathbf{7 2}}$ This is somewhat illogical, because an intentional termination should not result in less tax than a termination occurring as the result of an objective event. ${ }^{73}$ Nevertheless, the enacted scheme merely reflects a failure to accelerate the generation-skipping $\operatorname{tax} .^{74}$

More importantly, the expiration of a future interest or power is not a termination. ${ }^{75} \mathrm{~A}$ future interest or power is one whose enjoyment or existence depends upon a contingency which has not occurred at the time of the termination. Thus the death of a contingent remainderman, or of a potential appointee under a testamentary power held by a present or future beneficiary, would not constitute a taxable termination. ${ }^{76}$ (A person who possesses such a future interest or power, however, is a beneficiary for purposes of determining the existence of a generation-skipping trust.) The distinction between present and future interests is difficult to apply to situations in which the beneficiary might have been able to enforce fiduciary standards in a court of equity against a trustee but for the fact that the operative conditions, for example, support or emergency health needs, never occurred. While contingencies clearly beyond the control of the beneficiary should probably result in the categorization of the interest as future, the operative facts under many

panying note 87 infra. The phrase "if any" in that section, referring to the tax upon the termination of the interest of the grantor's spouse, appears to acknowledge the fact that the death of the spouse is not itself a taxable termination.

${ }^{72}$ Conference Report, supra note 21 , at 619 . A fortiori, a timely disclaimer would not be a taxable termination. I.R.C. $\$ \S 2518,2614$ (c).

${ }^{73}$ The gratuitous transfer of a right to income or a vested remainder, which is susceptible to actuarial valuation, would be subject to the gift tax. Treas. Reg. $\$ \S 25.2512-$ 9(c)-(d) (1970). Gift tax liability, however, would be less than that resulting from a deemed transfer of the entire trust under the generation-skipping tax provisions.

${ }^{74}$ Upon the expiration of the measuring life or other contingency, a generationskipping transfer would occur regardless of who then possessed the interest. There is no tax avoidance under the enacted scheme, because the identity of the person holding the terminating interest is irrelevant for purposes of determining tax liability; liability is determined with reference to the transferees. See text accompanying note 98 infra.

${ }^{75}$ I.R.C. \& $2613(\mathrm{~b})(1)$.

${ }^{76}$ See House REPORT, supra note 21, at 50. For example, the grantor creates a trust for the benefit of his child for life, remainder to the grantor's grandchildren who survive the death of the child. The death of any of the grandchildren during the child's lifetime does not give rise to a taxable termination. If, however, the grandchild holds a vested remainder interest or one which is not contingent on his surviving the preceding interest, which is capable of actuarial evaluation, his estate would be taxed under I.R.C. $\S 2033$. 
fiduciary standards are equivocal in this regard. ${ }^{77}$ Although the rule excluding the expiration of future interest from the definition of a taxable termination makes sense in itself, it is hard to reconcile with the inclusion of vested but non-possessory interests-those of potential appointees or distributees who have not in fact received anything ${ }^{78}$-given the practical similarity of both categories of interests.

A termination does not necessarily occur for purposes of imposing the tax at the time that it actually occurs. In several cases, the imposition of the tax with respect to a termination is postponed. In the case of a beneficiary who possesses more than one interest or power, the taxable event occurs at the time of the termination of the last such interest or power. ${ }^{79}$ Although some tax-avoidance techniques arising from this rule can be attacked by regulations, others might escape. ${ }^{80}$ An example might be a trust with the income payable to the child until age twenty-five, at which time the trustee is empowered to accumulate and in fact accumulates all of the income until the beneficiary's death. ${ }^{81}$

Postponement also occurs as a result of the implicit rule that the tax is only imposed once with respect to each generation. In cases where two or more younger-generation beneficiaries of a trust are assigned to the same generation, a taxable event occurs

${ }^{77}$ The need for support or emergency health funds is theoretically under the control of a beneficiary who refuses to work or attempts suicide, but his self-interest would presumably dictate against his creating the need by such means. This issue has raised problems under I.R.C. $\S \S 2036(a)(1)$ and 2038. See Lowndes $e t$ al., supra note 4, at $\S 8.11 \& 9.12$.

${ }^{78}$ See text accompanying notes 59-61 supra.

${ }^{79}$ I.R.C. $\$ 2613(\mathrm{~b})(2)(B)$.

81 I.R.C. $\S 2613(\mathrm{~b})(2)(\mathrm{B})$ expressly authorizes regulations to limit tax-avoidance techniques. An example would be a trust for a child where all of the income must be paid to him for 30 years, with the trustee being directed to thereafter pay the child five dollars out of the principal of the trust annually for the remainder of his lifetime. In this situation, the child's interest should terminate upon his attaining the age of 30 . In addition, contingent remainder interests might be ignored where the beneficiary also possesses a substantial present interest.

${ }^{81}$ So long as the beneficiary is a permissible recipient of trust assets, his interest would continue to exist. Nevertheless, the economic situation is virtually identical to the mandatory accumulation trust in the following example, which would not satisfy the requirements of postponement: income for the grantor's child until he reaches the age of 40 , then accumulated until his death, remainder to grandchildren. It is conceivable that the regulations will ignore minor trust interests specified in the trust for purposes of determining the time of termination, or they might contain a provision to the effect that the failure to receive any significant benefit for a certain period of time causes termination, even if the beneficiary continues to be a permissible recipient of the trust property. Under the latter rule, income subsequently paid to the beneficiary would give rise to a second taxable termination subject to the provision of I.R.C. $\S 2613(b)(7)(B)$, discussed in note 134 infra. 
only upon the last such termination. ${ }^{32}$ This version of the postponement rule would apply, for example, to a discretionary trust for the benefit of the grantor's children during their lives, the corpus to be distributed to his grandchildren. A taxable termination would occur only at the death of the last child. ${ }^{83}$ The rule does not apply per se to a case in which an interest of one who is not a same generation beneficiary breaks the succession, but the one generation/one tax principle is carried out in those instances by a different means. ${ }^{84}$

Insofar as the purpose of a generation-skipping tax is to achieve parity with situations where the property passes directly, the one generation/one tax principle is faulty, since the estate and gift taxes apply without regard to the generation assignment of the legatees and donees vis $\grave{a}$ wis that of the testators and donors. If the rationale of the principle is to avoid excessively frequent application of the tax resulting from successive deaths of beneficiaries of approximately the same age, a mechanism for dealing with the problem already exists in the section 2013 credit for prior transfers. ${ }^{85}$ Finally, the same-generation-beneficiary rule is conceptually redundant under the enacted scheme, because interests are transferred to a younger generation only at the time of the last successive termination event for the interests of a given generation. ${ }^{86}$

Postponement may occur in a third situation where a younger generation beneficiary predeceases a beneficiary of an older generation. In this situation, the "unnatural order of deaths" postponement rule provides that the later death of the older generation beneficiary constitutes the taxable event. ${ }^{87}$ This

${ }^{82}$ I.R.C. $\$ 2613(\mathrm{~b})(2)(\mathrm{A})$.

${ }^{83}$ See House REPORT, supra note 21 , at 50.

84 The postponement feature would not apply where another interest intervenes between those of the same-generation beneficiaries (for example, a trust for child $A$ for life, followed by one for grandchild $G$ for life, then for nephew $N$ for life, remainder to N's issue). Nevertheless, the tax base at N's death is reduced by the tax base at the time of $A$ 's death. The end result is that the amount ultimately taxed is the greater amount comparing the tax base at $A$ 's death with that at $N$ 's. See note 134 infra \& accompanying text; of. I.R.C. $\$ 2613(b)(2)(D)$ (postponement rules apply where person assigned to same or higher generation than person whose interest terminated acquires an interest immediately after, and as a result of, that termination).

${ }^{85}$ I.R.C. $\$ 2013$. The integration of this credit with the new rules is discussed in note 153 mfra \& accompanying text.

${ }^{86}$ For example, consider the discretionary trust example at text accompanying note 83 supra. Technically, however, the tax would apply but for the explicit statement of this rule. See note 70 supra. The postponement rule is often practically necessary to determine if the transferees are actually in a lower generation.

${ }^{87}$ I.R.C. $\$ 2613(\mathrm{~b})(2)(\mathrm{C})(\mathrm{i})$. An example would be a trust for the benefit of a 
rule seems to be based on no underlying principle; rather it appears to be oriented solely to the technical problem of ascertaining the ultimate transferees of the generation-skipping transfer. ${ }^{88}$ The technical problem would not exist, however, if the scheme were keyed to the shifting of enjoyment rather than to the skipping of generations per se. ${ }^{89}$

\section{B. Taxable Distribution}

A "taxable distribution" occurs when corpus (but not income), in the trust accounting sense, is distributed to a younger generation beneficiary, and just prior to the distribution there existed at least one other younger generation beneficiary of an older generation than that of the distributee. ${ }^{90}$ The rule for distributions is essentially a reinforcement of the provisions regarding terminations because a corpus distribution is essentially a partial termination of existing beneficial interests. Logically, the statute exempts an income distribution from the rule because it is in no sense a termination of an existing beneficial interest. ${ }^{91}$

The problem of defining trust accounting income for purposes of this rule is only partially addressed by the statute. ${ }^{92}$ In

nephew for life, then for the nephew's son for life, remainder to the grantor's great grandchildren, where the nephew's son predeceases the nephew. The death of the nephew's son would be a taxable termination, but it would be deemed to occur at the death of the nephew, which would also be a termination. For purposes of determining whether the requisite two separate generations of younger generation beneficiaries exist, the termination would presumably be deemed to occur at the time it actually occurred rather than the time it is deemed to occur under the postponement rule.

${ }^{88}$ Roughly speaking, there cannot be a generation-skipping transfer unless and until lower generation beneficiaries are assured of acceeding to the trust. But in the first example described in note 71 supra, even assuming that on the death of the child there is a possibility that the transferee following the charity might not be of a lower generation, the tax would apply anyway upon the child's death because no postponement rule is applicable to this situation. See note 140 infra.

${ }^{89}$ See text accompanying note 41 supra.

90 I.R.C. $\S 2613(\mathrm{a})(1)$. A loan or advance to a beneficiary, particularly if interestfree or bearing only nominal interest, will in all probability be treated by the Internal Revenue Service as a distribution. Such loans are to be reported to the Service. See HOUSE REPORT, supra note 21 , at 52.

${ }^{91}$ For example, assume a trust for the benefit of the grantor's child for life, remainder to the grantor's grandchildren. A corpus distribution to the grantor's child would not be a taxable event, because no younger-generation beneficiary of a higher generation than the distributee exists. Moreover, such a distribution would augment, rather than diminish, the estate of the child and would directly or indirectly appear in his unified transfer base.

${ }_{92}$ I.R.C. $\$ 2613$ (a)(2) provides that if, in a given year, distributions are made from both corpus and income to beneficiaries of different generations, the higher-generation beneficiaries are deemed to have received the income first. This rule has the effect of making distributions to the lower generation beneficiaries corpus distributions taxable 
particular, the result is unclear where distributions in a year aggregating in excess of trust accounting income are made to more than one younger generation beneficiary of the same generation. Three possibilities exist: (1) trace distributions to their actual source in income or corpus; (2) deem those distributions which are first in time to be first from income; or (3) allocate income or corpus among the beneficiaries on a pro rata basis. Application of either of the first two alternatives would invite the trustees to manipulate tax liability by choosing the source or order of distributions. The third alternative seems preferable and should be adopted in the regulations.

Moreover, a fundamental flaw exists in the basic definition of a taxable distribution. Such a distribution is deemed to occur where there is only one younger generation beneficiary of an older generation than the distributee. Thus a distribution would be fully taxable even where many of the beneficiaries whose interests are reduced occupy the same generation or one younger than that of the distributee. The reduction of their interests by virtue of the distribution would not result in a benefit to generations younger than their own. Such a result is inconsistent with the purported rationale of the generationskipping tax: to tax the trust assets as its benefits are transferred to succeeding generations. ${ }^{93}$

Not surprisingly, where an event is both a taxable distribution and a taxable termination, to the extent of the overlap, it is considered to be a taxable termination. ${ }^{94}$ An example is the expiration of a life estate giving rise to distributions in termination of a trust. ${ }^{95}$ The postponement rules are applicable only to ter-

under the new provisions. For example, assume a trust for the benefit of the grantor's issue in existence from time to time, until the death of the grantor's grandchild, $G$, remainder to the grantor's then surviving issue per stirpes. Assume further that in 1984 the trust accounting income is $\$ 5,000$ and that $\$ 4,000$ each is distributed to a child of the grantor and to one of his grandchildren. Regardless of the label placed on such distributions by the trustee, there is deemed to be a taxable termination to the extent of $\$ 3,000$. This result follows from the fact that the $\$ 4,000$ received by the higher generation beneficiary is deemed to be income, leaving only $\$ 1,000$ of trust accounting income for the grandchild. The remaining $\$ 3,000$ received by the grandchild is therefore treated as a distribution from corpus.

${ }^{93}$ For example, assume a trust from which the income is to be paid in equal shares to grantor's son $A$, grandchild $B$, and grandchild $C$, with corpus payable to any of them according to their health needs. A corpus distribution to $C$ will presumably be fully taxable even though only one-third of it is really a generation-skipping transfer.

${ }^{94}$ I.R.C. \& 2613(b)(7)(A).

${ }^{95}$ A distribution is not considered to be a termination in every instance in which it is, in fact, a termination. 
minations. The distinction between taxable terminations and distributions is also significant in the computation and payment of the tax.

\section{IMPOSITION OF THE TAX}

\section{A. Deemed Transferor}

The tax base and tax rates are determined with reference to the "deemed transferors" of the property in connection with a taxable termination or distribution. ${ }^{96}$ This term is generally defined, in a taxable termination or distribution, as that parent of a "transferee" (as defined below) ${ }^{97}$ who is more closely related to the grantor. ${ }^{98}$ However, where such parent is not himself a younger generation beneficiary of the trust and the transferee has an ancestor, related by blood or adoption to the grantor, who is a younger-generation beneficiary, the ancestor becomes the deemed transferor. ${ }^{99}$ An example is a trust for the grantor's child for life, remainder to the child's grandchild; here, the child as opposed to the grantor's grandchild is the deemed transferor. ${ }^{100}$ It is not clear, unfortunately, whether the exception or the general rule applies where the parent or ancestor was technically a beneficiary but never possessed anything more than a future interest or power. ${ }^{101}$

Under the general rule deemed transferors who are parents

${ }^{96}$ I.R.C. $\S 2602(a)(1)$.

${ }^{97}$ See text accompanying notes 104-15 infra.

98 I.R.C. $\$ 2612(a)(1)$. Where the transferee is unrelated to the grantor, the deemed transferor is the transferee's parent having the closer "affinity" to the grantor - meaning that he is named in the trust instrument, or, perhaps, that he was an employee or friend of the grantor. See House REPORT, supra note 21, at 56 . A parent who is related to the grantor by blood or adoption is deemed to be more closely related to him than one related by marriage. I.R.C. $\$ 2612$ (b).

${ }^{\text {99 }}$ I.R.C. § 2612(a)(2).

${ }^{100}$ The grantor's great-grandchild is the transferee, and ordinarily his parent, the grantor's grandchild, would be the deemed transferor. Under $\$ 2612(a)(2)$, however, because the grantor's grandchild is not a beneficiary of the trust, and the transferee has an ancestor-the grantor's child (grandfather of the transferee)-who is a beneficiary and related to the grantor, that ancestor becomes the deemed transferor.

${ }^{101}$ Compare I.R.C. $\$ 2613(b)(1)$ (excluding future interests from taxable terminations) with 1.R.C. $\S 2613$ (c)(3) (including future interests within the definition of beneficiaries). The latter provision should prevail in interpreting the rules concerning deemed transferors. To illustrate the problem, assume a trust for son $A$ for life, remainder to $A$ 's issue. $A$ is survived by his son $S$ and the children $X$ and $Y$ of his deceased daughter $T . T$ was a beneficiary, but never had more than a future interest. It is unclear whether $T$ (the general rule) or $A$ (the exception) is the deemed transferor of the portion going to $X$ and $Y$. 
of the transferee may in fact have never enjoyed the property. ${ }^{102}$ Although a parent of a transferee might have received an indirect economic benefit, this would not generally be the case. ${ }^{103}$ In any event, this definition of deemed transferor is hard to justify where a person, other than the transferee's non-beneficiary parent or ancestor, enjoyed the property immediately prior to accession or receipt by the transferee.

\section{B. Transferee}

In order to determine the identity of the deemed transferor the identity of the transferees must first be ascertained. Ordinarily, a "transferee" is a distributee or a person who accedes to a succeeding trust interest. More than one tax base may arise from a taxable event where various deemed transferors are identified with reference to amounts deemed received by their respective transferees. Indeed, if one of several transferees is not of a lower generation than that of the person whose interest terminated, apparently the share received or acceded to by that transferee is not the subject of a generation-skipping transfer. An example is a trust for the grantor's child $A$ for life, remainder to the grantor's issue per stirpes, where $A$ was survived by his children and his sister. Although a taxable termination seems to have occurred with respect to only half the trust, the statute is ambiguous on this important point, and the legislative history offers no helpful clues..$^{104}$

${ }^{102}$ For example, assume a trust for the benefit of the grantor's child $A$, remainder to the children of the grantor's child $B$. The deemed transferor is $B$, fot $A$, even though $B$ never enjoyed the property. The exception does not apply because $A$ is not an ancestor of the beneficiaries- $B$ 's children. The same result occurs in a trust for the grantor's nephew for life, remainder to the grantor's grandchildren; one or more children of the grantor would be the deemed transferors.

${ }^{103}$ For example, the parent's obligation of support would not normally be diminished even in the case of a minor child transferee. Of course, the transferee may be a prosperous adult.

${ }^{10 .}$ I.R.C. $\$ 2613(b)(1)$ states that a termination, to be taxable, only requires that an interest of a younger generation beneficiary, who is assigned to a generation older than any other younger generation beneficiary, terminates. This seems to contradict the result suggested in the text. The tax base and rates, however, are determined with respect to the deemed transferor. See text accompanying note 96 supra. Suppose a trust was created by a grantor for his child for life, with remainder in equal shares to the grantor's spouse and the grantor's grandchild and assume that both survive. The deemed transferor with respect to the spouse's half would be one of the grantor's parents-in-law. A tax on this portion seems to have been clearly unintended, in part because there is no way of determining which in-law has a closer "affinity" to the grantor under I.R.C. $\$ 2612$ (a)(I), which is based upon an assumption that the deemed transferor is in a generation younger than that of the grantor. See note 98 supra. Hope- 
The definition of transferee in the Act is subject to further refinement. With respect to terminations, the transferees are those who accede to present interests in the trust. ${ }^{105}$ An exception to this rule, however, would be where no transferee has a present interest. ${ }^{106}$ Moreover, as previously suggested, the distinction between present and future interests is unclear in certain situations. ${ }^{107}$

The identification of transferees is accomplished after application of the postponement rules. In fact, the postponement rules are necessitated partly by the purely technical consideration of facilitating the identification of transferees, and hence of deemed transferors. ${ }^{108}$ This rather involved process could have been obviated had the wholly artificial concept of deemed transferor not been adopted.

In some cases the identification of transferees or their shares of the property might be uncertain due to the existence of discretion or a power of appointment in a trustee or other person with respect to acceding beneficiaries. ${ }^{109}$ For such even-

fully, the regulations will clarify this point along the lines indicated. $C f$. note 93 \& accopanying text supra (discussing a similar situation in the context of taxable distributions).

${ }^{1115}$ See I.R.C. \$ 2613(b)(1).

${ }^{106}$ The "present" interest rule has at least one exception. Assume a trust to the grantor's child for life, followed by a direction to pay the income to a charity for ten years, with remainder to a grandchild. Upon the death of the child, the grandchild is a transferee even though his enjoyment is postponed. CONFERENCE REPORT, supra note 21, at $619 \mathrm{n} .2$. Essentially the same problem arises in the context of mandatory accumulation trusts. Assume a trust for the grantor's child for life, after which the trustee is to accumulate income for the next 21 years, remainder to the grantor's issue then surviving. Presumably the death of the child gives rise to a taxable termination, even though the transferees cannot be identified at the time of death. None of the transferees has a present interest, nor would any of the postponement rules apply.

${ }^{107}$ See text accompanying notes 76-77 supra. For example, the grantor creates a trust for his daughter with corpus to be distributed to his grandchildren for their college education. Grandchild $B$ dies at the age of 16 , before graduating from high school. Did $B$ possess a present or future interest? What about an "extraordinary health needs" standard in a case in which the beneficiary never became ill? See note 77 supra.

${ }^{108}$ For example, assume a trust providing income to the grantor's children $A, B$ and $C$ for life, according to the trustee's discretion, with remainder to the grantor's great-grandchildren surviving upon the death of the survivor of the grantor's children. Assume further that $A$ dies first. If this event were taxable, the transferees could not possibly be identified, since $B$ and $C$ (being of the same generation as $A$ ) would not be transferees. The postponement rules, see text accompanying notes 80-89 supra, delay taxation until the subsequent death of the survivor of $B$ and $C$ when the identity of the transferees will be ascertainable. See House Report, supra note 21, at 50, 57; text accompanying note 88 supra.

${ }^{109}$ For example, assume a trust for the benefit of the grantor's children $A$ and $B$ until the death of the survivor, then for the benefit of those of the grantor's issue who are surviving from time to time until the expiration of 21 years, remainder to the issue 
tualities, the regulations are to create a set of presumptions fixing the identity and shares of transferees. ${ }^{110} \mathrm{~A}$ principal presumption would be that where the transferees are designated as a class, such as "issue," it would be presumed that discretion would be exercised on a per stirpes basis.11 If, however, the potential transferees are all in the same generation or are named persons, it would be presumed that discretion would be exercised on a per capita basis. If the class of potential appointees were unusually broad, it would be presumed that the issue of the grantor would be favored to the exclusion of others. ${ }^{12}$ This aspect of the new provisions is most objectionable from a conceptual viewpoint, because the tax may be imposed with respect to a deemed transferor who not only never enjoyed the trust property himself but who also is an ancestor or parent of one or more transferees who might also never enjoy the property, depending on the ultimate exercise of the trustee's discretion.

Finally, where an entity, rather than an individual, is a successor beneficiary of the trust, each individual having an indirect interest or power in the trust through such entity is treated as a beneficiary, and is assigned to a generation under the provisions of secton $2611(\mathrm{c}) .^{113}$

Where powers, rather than interests, expire, the concept of the transferee virtually breaks down, ${ }^{114}$ unless the transferees are deemed to be those who then hold interests in the trust and not those who accede to the power. ${ }^{115}$

of the grantor. Upon the death of the children, the potential transferees can be ascertained but their respective shares cannot be because that is within the trustee's discretion.

110 I.R.C. $\$ 2613(b)(3)$.

"III. For example, assume that the grantor creates a trust for the benefit of his child for life, and then, according to the trustee's discretion, among a group consisting of the grantor's grandchild $G$ and his issue, with remainder upon the death of $G$ to $G$ 's issue. Upon the death of the grantor's child, the transferee would be deemed to be $G$, despite the existence of a larger class of potential transferees, because the discretion would be deemed to be exercised on a per stirpes basis and $G$ is the ancestor of all of the other potential transferees. See CONFERENCE RePORT, supra note 21, at 619 n.3.

112 See House RePORT, supra note 21, at 57 n.15.

${ }^{113}$ I.R.C. $\$ 261 \mathrm{l}(\mathrm{c})(7)$. This rule does not apply to charitable trusts or tax-exempt corporations. See HOUSE REPORT, supra note 21 , at 57.

${ }^{114}$ Assume that the power is acceded to by persons holding the power jointly. It can be assumed that the co-holders are each transferees as to half the power. Yet the coholders may not be able to appoint to themselves. Or perhaps a power held jointly is not a power at all, see note 55 supra \& accompanying text, and hence the co-holders are not beneficiaries. The situation becomes even more complex if they are considered as beneficiaries, but one of them is not of a lower generation than the person whose power expired.

115 This approach would in turn probably invoke the presumptions described and 


\section{Tax Base}

In the case of a taxable distribution, the tax base is simply the amount distributed plus any generation-skipping tax with respect thereto that was paid by the trustee out of the income or corpus of the trust. ${ }^{116}$ This amount is allocated to the appropriate deemed transferors and the tax is computed as described herein. In the case of a termination of an interest or power, the portion of the value of the trust involved in generation-skipping transfers is allocable among the deemed transferors, in accordance with the foregoing principles, ${ }^{117}$ and the tax determined in a like manner. ${ }^{118}$ Valuation of the transfer is to be determined as of the time of the taxable event, taking into account the application of the postponement rules. If a taxable termination occurs at the death of the deemed transferor, the trustee can elect an alternate valuation date in accordance with section 2032, independently of the decision of the executor or administrator of the deemed transferor's estate. ${ }^{119}$

criticized in notes 110-12 supra \& accompanying text, because the interests may not be fixed due to the continued existence of trustee discretion. Also, if some of the transferees are not of a lower generation than the person whose power expired, the problems mentioned in note 104 supra \& accompanying text are raised.

${ }^{116}$ I.R.C. $\$ 2613(a)(3)$. In the case of taxable distributions, the tax is supposedly borne by the distributees. I.R.C. $\$ 2603(\mathrm{a})(\mathrm{I})(\mathrm{B})$. It follows that if the trust pays all or part of the tax, the payment is treated as an additional distribution. See House REPORT, supra note 21 , at 53. In addition, the satisfaction of the distributee's debt obligation would appear to create income tax liability for the distributee over and above that resulting from application of the rules of subchapter J, I.R.C. \$\$ 641-92. See Johnson v. Commissioner, 495 F.2d 1079 (6th Cir.), cert. denied, 419 U.S. 1040 (1974).

${ }^{117}$ See text accompanying notes 96-102 supra.

${ }^{118}$ See I.R.C. $\$ 2602(a)(1)(A)$. The tax base, prior to allocation among deemed transferors, would normally be the entire trust with respect to which the expiring interest or power related, even though the interest or power itself was not related to the entire income or corpus. Examples are trusts over which a power to invade corpus to the extent of the greater of $5 \%$ or $\$ 5,000$ is held or in which the younger generation beneficiary could have received all or only part of the income or corpus according to the trustee's discretion. See note 47 supra. The portion of the trust, if any, that is transferred to one who is not of a lower generation than the beneficiary whose interest or power terminates should not be allocated to any deemed transferor and should not be taxed. See text accompanying note I04 supra. A similar result would occur where the separate share rule, described in note 193 infra \& accompanying text, holds that only a portion of the property is deemed to be transferred. The same principle should apply where the beneficiaries of the interest terminated had a right only to a fixed amount or share of the income from the trust, even though the separate share rule would not apply per se to a case in which the transferees will have a right to all of the trust income. The statute and legislative history are unclear on this point.

119 I.R.C. $\$ 2602(d)(1)$. I.R.C. $\$ 2032$ provides that the valuation date may be six months after the death of the deemed transferor or the date of any disposition of the property within six months of the death. This rule also applies, upon the death of the survivor of a class of beneficiaries where the same generation beneficiary rule post- 


\section{1. $\$ 250,000$ Exclusion}

A deemed transferor who is the grantor's child has a lifetime $\$ 250,000$ exclusion to be applied in reduction of generation-skipping transfers to the grantor's grandchildren. ${ }^{120}$ The innocent phrase "transfers to the grandchildren" is apparently to be construed as a term of art. A passage in the report of the Conference Committee that reported out the Act suggests that the exclusion is available in any case where the property vests in the grandchild, even where the property continues to be held in trust for the grandchild's benefit. ${ }^{121}$ It is apparently not enough that the grandchildren be transferees for purposes of qualifying their parents as deemed transferors. Without a vesting requirement tax avoidance possibilities would exist, ${ }^{122}$ but it is not clear whether "vesting" is limited to the property law meaning of the term ${ }^{123}$ or whether it also includes the possession by the grandchild of a general power of appointment. ${ }^{124}$

poned the imposition of the tax. See text accompanying notes 82-84 supra. A trustee can elect the alternate valuation date regardless of the choice made by the executor or trustees of other trusts. The rule applies only with respect to taxable terminations and not to distributions. See Confference Report, supra note 21, at 615. Although it is not stated whether a generation-skipping transfer that was deemed to occur "after" the deemed transferor's death under the principles of I.R.C. \$ 2035 (transactions within three years of death), as applied by I.R.C. $\$ 2602$ (e), qualifies for the alternate valuation date, the regulations should decide this question in the affirmative. For a discussion of $\$ 2602(\mathrm{e})$, see note 144 infra \& accompanying text.

${ }^{120}$ I.R.C. $\$ \S 2613(a)(4)(A), 2613(b)(5)(A), 2613(b)(6)$. The exclusion is to apply even where the transfer to the grandchild occurs by reason of the exercise (or lapse) of a power of appointment. CONFERENCE REPORT, supra note 21, at 618. For purposes of the exclusion, trusts established by the grantor's spouse are consolidated with those created by the grantor. Where there are several distributions or terminations flowing through the same deemed transferor, the exclusion is to be applied against them chronologically until fully utilized. House REPORT, supra note 21, at 52-53.

121 Conference Report, supra note 21, at 618.

122 There would be a tax avoidance possibility in a trust for the grantor's child for life, then to the grandchildren for one year, then to the great-grandchildren. Not only would the exclusion be obtained, but the grandchildren, who would be deemed transferors upon the expiration of their interests, will probably be in a low tax bracket. Alternatively, a trust for the grantor's child, then to the grandchildren and their spouses, remainder to surviving issue, could avoid and postpone any tax until the termination of the trust.

${ }^{123}$ In this context, vesting would mean that if the grandchild died prior to the termination of the trust the corpus would be payable to his estate. Cf. I.R.C. $\S \S 2056(\mathrm{~b})(1)(\mathrm{A})$ (estate tax) \& 2503(c)(2)(B) (gift tax).

${ }^{124}$ The Conference Report, supra note 21 , at 618 , after describing the exclusion, states:

This exclusion is to be available in any case where the property vests in the grandchild (i.e., the property interests will be taxable in the grandchild's estate) as of the time of the termination or distribution, even where the property continues to be held in trust for the grandchild's benefit .... 
It seems doubtful if a testamentary (or even an inter vivos) general power of appointment in isolation would be indicative of a "transfer" to the donee of the power, but it is not stated whether the grandchild must possess an income interest in addition to the general power of appointment and, if so, what kind of income interest it must be. If Congress had desired to prescribe the marital deduction terminable interest rule of section 2056(b) it could easily have done so. ${ }^{125}$ It is inexcusable that so crucial an issue should be unresolved at this point. There are three possible interpretations of the statute. In order for the child to receive the exclusion: (1) there must be an outright transfer to the grandchild; or (2) a similar rule modified by a terminable interest provision; or, (3) it is enough that the grandchild be a transferee of the child deemed transferor. ${ }^{126}$

There is a degree of irony in this situation because the $\$ 250,000$ exemption is totally without justification in the first place. ${ }^{127}$ The single stated rationale appears to be a remark in a House report recording the Ways and Means Committee's belief that a $\$ 1,000,000$ trust should be sufficient to provide for the needs of each child, even where the child might be a victim of disability or other hardship. ${ }^{128}$ The availability of the exclusion,

If the grandchild possesses a general power of appointment, the property will be taxable to his estate. I.R.C. $\$ 2041$ (a)(2). Although powers of appointment are not mentioned, and although acquisition of such a power does not constitute vesting per se, elsewhere in the Code the possession of a general power of appointment is treated as the functional equivalent of vesting. I.R.C. \$§ 2056(b)(5), 2057(c), 2503(c)(2)(B), 2523(e).

${ }^{125}$ In enacting the new orphan's exclusion in I.R.C. $\$ 2057$ (c), Congress did explicitly incorporate the terminable interest rule of I.R.C. $\$ 2056(\mathrm{~b})$. Therefore, Congress should not be deemed to have intended its application to the first-generation exclusion.

${ }^{126}$ The phrase "transfer to the grandchildren" could be construed merely to refer to the situation in which a grandchild of the grantor is a transferee, which can occur where he accedes to an income interest which would not be includible in his gross estate. The statement in the Conference Report, supra note 21 , at 618 , might be interpreted expansively to consider a grandchild as a transferee even though the trustee is required to accumulate income during his minority. However, if this was the intent, the Conference Committee (1) should have referred to mandatory accumulations, and (2) would probably have stated this rule in the context of defining transferees rather than in the narrower context of describing the exclusion.

127 There was no exclusion in either the initial version of the bill, H.R. 13966, $\S 7$ (a), 94th Cong., 2d Sess., 122 Cong. Rec. H4848-49 (daily ed. May 24, 1976), nor in the version passed by the Senate, H.R. 10612, $\S$ 2202(a), 94th Cong., 2d Sess., 122 CoNG. Rec. S13797 (daily ed. Aug. 6, 1976). An exclusion of $\$ 1,000,000$ appeared in the bill as reported out of the House Ways and Means Committee, H.R. 14844, § 7(a), 94th Cong., 2d Sess., 122 Cong. Rec. H7758 (daily ed. July 26, 1976), and appears in the House Report, supra note 21, at 52.

${ }^{128}$ HOUSE REPORT, supra note 21 , at $53 \mathrm{n} .8$. The $\$ 1,000,000$ figure was reduced to $\$ 250,000$ in conference without comment. CONFERENCE REPORT, supra note 21 , at 614 , 618. 
however, is not dependent upon the existence of any hardship. Nor is it evident that the needs of a child would have priority over those of a grandchild. In fact, a grandchild obviously would more likely be a minor dependent. Furthermore, a child could be a deemed transferor, and thus claim the exclusion, even when he was not a beneficiary of the trust. ${ }^{129}$ Perhaps the most telling criticism is that the burden of the generation-skipping transfer tax does not fall upon the child, but upon the successors in interest. ${ }^{130}$ Finally, the limited exclusion cannot be rationalized within any of the broad theories for imposing a generationskipping tax, ${ }^{131}$ including the principles of neutrality and periodicity cited by the congressional tax committees. ${ }^{132}$

\section{Deductions}

Other deductions from the tax base are derived from the structure of the tax. If a deemed transferor with respect to a taxable event is a member of a generation that includes another member who was a deemed transferor in a prior taxable termination involving property of the trust, there is a deduction for the amount subjected to tax at the earlier taxable event. ${ }^{133}$ This deduction, which follows from the principle of one tax per generation, appears to be incorrectly drafted. ${ }^{134}$ 19-20.

129 See text accompanying note 102 supra.

${ }^{130}$ See text accompanying note 138 infra.

${ }^{131}$ See text accompanying notes 15-20 supra.

${ }^{132}$ See House RePORT, supra note 21, at 46-47; SenAte RePORT, supra note 19, at

${ }^{133}$ See I.R.C. $\$ 2613(b)(7)(B)$.

${ }^{134}$ For example, assume that a trust was established by the grantor for $A$ for life, then to $B$ for ten years, then to $C$ for life, remainder to $D$ and his heirs. Assume further that $A$ and $C$ are higher-generation beneficiaries than $B$ and $D$. Disregarding the $\$ 250,000$ exclusion, if the value of the trust upon the death of $A$ was $\$ 300,000$ and the value of the trust on the death of $C$ was $\$ 500,000$, the tax base upon the death of $C$ would be merely $\$ 200,000$. This result assumes that $A$ is in the same or a lower generation than $C$ and that $B$ is in the same or a higher generation than $D$, in accordance with I.R.C. $\$ 2613($ b)(7)(B)(i), (ii). For example, the rule would apply if $A$ were a grandchild, $B$ a great-grandchild, $C$ a child, and $D$ a great-great-grandchild of the grantor. On the other hand, a trust for a child $A$, great-grandchild $B$, child $C$, and grandchild $D$, in that order, would apparently not qualify for the deduction upon the death of child $C$ because $B$ is in a lower generation than $D$. This result is the reverse of what it should be: in the first example, the transfer from $C$ to $D$ effectively skips a second generation, whereas in the second case the transfer from $C$ to $D$ leaves the property in a higher generation than the transfer from $A$ to $B$. See House Report, supra note 21 , at 53 \& n.9. I.R.C. $\S 2613(\mathrm{~b})(7)(\mathrm{B})(\mathrm{iii})$ adds that this rule does not apply where a transfer would have the effect of avoiding a generation-skipping tax with respect to any transfer. The legislative history offers no clue as to what is intended by this provision. See CONFERENCE RePORT, supra note 21, at 620. 
Another deduction comes into play when the postponement rule has been applied because of the unnatural order of deaths of beneficiaries of different generations. ${ }^{135}$ In such a case, the termination of the interest of the higher generation beneficiary may cause the imposition of a double tax. The tax, if any, ${ }^{136}$ is first imposed on the value of the trust at the time of the death of the higher generation beneficiary. The tax is then imposed again upon the same value of the property with respect to the lower generation beneficiary, reduced by the amount of any tax paid with respect to the first imposition. ${ }^{137}$ The latter tax is attributable to the postponed termination. The provisions are designed to insure that the outcome roughly reflects the result that would have occurred absent the application of the postponement rule. ${ }^{138}$

Some conventional transfer tax deductions are also allowed. Certain losses and administration expenses of the trustee or distributee, which have not previously been deducted for estate or income tax purposes, may be deducted from the tax base if the taxable event occurs at or after the death of the deemed transferor. ${ }^{139}$ Similarly, if property passes to a charity a deduc-

${ }^{135}$ I.R.C. $\$ 2613$ (b)(2)(c); see text accompanying notes 87-89 supra.

${ }^{136}$ There may be no tax, since the beneficiary may not have been the member of a skipped generation.

${ }^{137}$ I.R.C. $\S 2613(b)(2)(C)(i i)$.

${ }^{138}$ The Conference Report cites the example of a trust for the benefit of the grantor's nephew and the nephew's son for their joint lives, with remainder to the nephew's grandson. If the nephew's son predeceases the nephew, the unnatural-order-of-deaths postponement rule applies. Upon the death of the nephew, the double termination event occurs. The first termination is deemed (contrary to fact) to be with respect to the nephew, and a tax is imposed according to the normal rule. Then a tax is levied with respect to the nephew's son, reducing the tax base by the amount of tax imposed with respect to the nephew. In this situation, the deemed transferor for the first transfer would be the nephew and for the second transfer the nephew's son. Nevertheless, the result is not exactly the same as would have occurred absent the application of the postponement rule, because the initial tax base for both terminations is the value of the trust assets at the time of the later death of the nephew. See CoNfERENCE REPORT, supra note 21 , at 616 .

139 I.R.C. \$ 2602(c)(5)(B); House RePorT, supra note 21, at 55. According to I.R.C. $\S 2602(e)$, a taxable transfer within three years of the deemed transferor's death is deemed to occur "after" his death, and hence would qualify for this deduction. In the case of a termination, the deductible expenses are those which would have been allowable under I.R.C. $\$ \$ 2053 \& 2054$ if the trust had been an estate. In the case of a taxable distribution, the deductible expenses are those connected with the determination, collection or refund of the generation-skipping tax. The scope of this provision is somewhat unclear. For example, could sales commissions not deductible under $\$ 2053$ because not "necessary" to the administration of the trust, see Treas. Reg. $\$ 20.2053-3$ (d)(2) T.D. $6826,1965-2$ C.B. 369 , be deducted in the generation-skipping context? Cf. $\S 2009$ (d), Tax Reform Act of 1976 (amending I.R.C. $\$ 642(\mathrm{~g})$, preventing the allow- 
tion will be allowed. ${ }^{140}$ No provision is made, however, for a marital deduction or orphan's exclusion within the generationskipping tax rules, even where the transferee is the deemed transferor's spouse or orphaned child. ${ }^{141}$

\section{Computation of the Tax}

\section{Tax Rate}

The tax is computed under the unified transfer tax tables as if the tax base were the subject of a taxable transfer by the deemed transferor. ${ }^{142}$ If the generation-skipping transfer occurs during the deemed transferor's lifetime, the tax base is added to the deemed transferor's cumulative prior gifts and generationskipping transfers. If his death has occurred or is itself the event giving rise to the taxable termination, the tax base is treated as a second taxable estate. The cumulative tax base thus consists of post-1976 gifts, prior generation-skipping transfers, the taxable estate, and the present generation-skipping transfers. The tax computed on the cumulative tax base is then credited with the tax paid on the transfers represented in the base that occurred prior to the present generation-skipping transfers. In short, the generation-skipping transfer is taxed at the deemed transferor's highest marginal rate brackets. ${ }^{143}$ If the generation-skipping

ance of both a deduction under I.R.C. $\$ 2053$ and a reduction in the amount realized upon sale in determining gain or loss).

140 I.R.C. $\$ 2602(c)(2)$. If all of the property passes to a charitable transferee, there would be no tax at all. Assume a trust for the grantor's child $C$ for life, then for charity for ten years, remainder to grandchild. The death of $C$, not the expiration of ten years, would be the taxable event.

${ }^{141}$ See 1.R.C. $\$ 2602(c)(1)$. A transfer to a beneficiary's spouse would not be subject to the tax in any event because generational requirements would not be met. See note 70 supra \& accompanying text. If the death of the grantor's spouse were a taxable transfer under a generation-skipping tax, then logically the spouse's interest could qualify for the marital deduction. Such a rule would effectively eliminate the need for giving the spouse a general power of appointment within IRC \& 2056(b)(5). However, in so far as power of appointment trusts are already utilized to deprive spouses of lifetime control over assets, a rule which would effectively deprive them of even testamentary control over such assets may be socially and politically undesirable.

The orphan's exclusion is found in I.R.C. $\$ 2057$, and is available only if the decedent does not leave a surviving spouse. The deduction equals $\$ 5,000$ multiplied by the number of years under the age of 21 of each minor child. The orphan's exclusion contains a modified terminable interest rule similar to that found in I.R.C. $\$ 2056$ (b). See note 125 supra.

${ }^{142}$ For an outline of the unified transfer tax system, see note 29 supra.

${ }^{143}$ See I.R.C. $\$ 2602(a)$. In the case of a deemed transferor who is a non-resident and not a citizen of the United States, and in which the transfer occurred at or after his 
transfer occurs within three years of the deemed transferor's death, the new contemplation of death rule applies, and the transfer is deemed to occur just after the deemed transferor's death. ${ }^{144}$

Although inconsistent with the foregoing, the generationskipping transfers are not part of a deemed transferor's cumulative tax base for conventional estate and gift tax purposes. ${ }^{145}$ Therefore, estate and gift taxes are not increased by generation-skipping transfers, probably on the theory that they are beyond the control of the deemed transferor. This rationale is irrelevant, however, because the tax is really borne not by the transferors but by the transferees, who lack control not only over generation-skipping transfers but also over gifts and bequests received by them. Thus there appears to be no compelling reason why the generation-skipping tax cannot be more closely integrated with the estate and gift taxes.

The tax rate may be affected by the interplay of the new rules with the marital deduction. If the taxable transfer occurs (or is deemed to occur) at or within nine months after the date of the deemed transferor's death, the generation-skipping transfer is added to the deemed transferor's gross estate for purposes of determining the maximum marital deduction. ${ }^{\mathbf{1 4 6}}$ If this feature is used to advantage, the marginal rates applicable to both the generation-skipping transfer and the taxable estate may be reduced. ${ }^{47}$ This provision may be undesirable, however, because its applicability will probably be determined, with undesirable and unintended results, by instruments drafted without knowledge of the provision's existence or import. In any event,

death, only the taxable estate, and not prior gifts, is considered for the purpose of determining the tax rate. I.R.C. \& $2614(\mathrm{~b})(2)$.

${ }^{144}$ I.R.C. $\$ 2620$ (e); CONFERENCE REPORT, supra note 21 , at 617 . For a discussion of an issue ancillary to this rule, see note 108 supra. Under I.R.C. \& 2035, amended by the Tax Reform Act of 1976, $\S 2001$ (a)(5), a transfer within three years of the decedent's death is included in the decedent's gross estate without regard to the decedent's motive.

${ }^{145}$ See House REPORT, supra note 21, at 56 n.13. Of course, a generation-skipping transfer is included in the deemed transferor's cumulative tax base for purposes of calculating the tax rate applicable to subsequent generation-skipping transfers deemed to be made by him.

${ }^{146}$ I.R.C. $\$ 2602(\mathrm{c})(\mathrm{J})(\mathrm{A})$.

${ }^{147}$ See House REPORT, supra note 21, at 54. A generation-skipping transfer occurring within three years of the deemed transferor's death would also come within this rule. See note 128 supra. The Conference Report, supra note 21 , at 616 , indicates that marital deduction bequests are not to be deemed terminable interests simply because the facts fixing the amount thereof might occur during the nine-month period following the deemed transferor's death. 
the transfer does not itself qualify for the estate tax marital deduction. ${ }^{148}$

\section{Credits}

The generation-skipping tax is subject to any unused portion of the deemed transferor's unified transfer tax credit. ${ }^{149}$ That this rule applies only if the taxable event occurs (or is deemed to occur) at or after the death of the deemed transferor seems inequitable, but it prevents certain tax-avoidance possibilities. ${ }^{150}$ It is not clear whether the unused credit referred to is that existing at the deemed transferor's death, after the estate tax, or that existing as of the later generation-skipping transfer. This issue will be significant where the deemed transferor's death occurs between 1977 and 1980 inclusive. ${ }^{151}$

The section 2013 credit for prior estate transfers within ten years is to be fully available. ${ }^{152}$ This credit will now apply where a generation-skipping tax was imposed with respect to a deemed transferor at or after his death, and subsequently the same property is taxed again. In other words, the generation-skipping tax is treated as a prior estate tax, and is itself deemed to be available for the section 2013 credit. ${ }^{153}$ If the "generation" concept is

${ }^{148}$ The property is neither includible in the deemed transferor's gross estate nor does it "pass" from him to his spouse as required by I.R.C. $\S \S 2056$ (a) \& (d). For further discussion on the interplay of the generation-skipping tax with the marital deduction, see text accompanying notes 183-89 infra.

${ }^{149}$ See I.R.C. \$ 2602(c)(3). See also note 29 supra.

${ }^{150}$ For example, generation-skipping transfers could be routed through living deemed transferors in low tax brackets with large unused credits. An example would be a trust for the benefit of a series of beneficiaries, each interest to be cut off at age 30 . The Rule Against Perpetuities would limit the tax-avoidance potential of such schemes. See note 8 supra.

${ }^{151}$ The unified transfer credit is phased in gradually during this period. See I.R.C. $\S 2010$ (b); note 188 infra. Arguably, the amount of the credit is determined as of the time of the deemed transferor's death. However, the date of the transfer is the more appropriate time in the present context. A minor problem concerning the unused unified transfer tax credit is that for estate tax purposes the credit is used prior to the other available credits, thereby potentially reducing the amount available for the generation-skipping tax. I.R.C. \$§ 2011(f), 2013(e)(1)(A), 2014(b)(2), as amended \& added by Tax Reform Act of 1976, $\$ 2001$ (c)(1)(A), (C), (G).

${ }^{152}$ See I.R.C. $\$ 2602(c)(4)$.

${ }^{153}$ Id.; see I.R.C. $\$ 2013$ (g), added by the Tax Reform Act of 1976, $\$ 2006(\mathrm{~b})(2)$; House REPORT, supra note 21 , at 54. The subsequent tax must be an estate tax or a generation-skipping tax, not a gift tax. Under prior law, one who acquired a life estate by bequest was deemed to have acquired, for purposes of I.R.C. $\$ 2013$, the actuarial value (at the time of the grantor's death) of the life estate, even though the life estate was not itself subject to estate tax in the hands of the life tenant. Treas. Reg. $\$ 20.2013-4$ (a) T.D. $6296,1958-2$ I.R.B. 457. Henceforth, the excess of the value of the property over such actuarial value will also be deemed a transfer by the grantor to the 
so important that the new tax should be based upon it, then the section 2013 credit should have been expanded to conform more closely to that concept. ${ }^{154} \mathrm{Had}$ this been done the definition of "generation" could have been drafted more realistically, or even omitted, and the one generation/one tax concept abandoned. ${ }^{155}$

The section 2011 credit may be taken where the transfer is also subject to state death tax, ${ }^{156}$ but the section 2012 credit for prior gift tax is of course not available. ${ }^{157}$

\section{E. Liability and Procedures}

The tax is not owed by the deemed transferor or his estate. Rather, in the case of a taxable termination, it is payable out of the trust property and, in the case of a taxable distribution, the distributees are personally liable. ${ }^{158}$ Recall that an event that is both a termination and a distribution with respect to any prop-

life tenant, who is a deemed transferor, for purposes of applying the $\S 2013$ credit. See CONFERENCE REPORT, supra note 21 , at 616 . The $\$ 2013$ credit is not available where the initial transfer was a taxable gift. See note 157 infra \& accompanying text.

154 The present credit is phased out as the time spread between the imposition of two "estate taxes" increases from three to ten years. I.R.C. § 2013(a). This phase-out could be stretched to 20 or 30 years in order to bring the credit in greater conformity with a "generation" or "periodicity" notion. Both concepts, however, are equally irrelevant to a conceptually pure transfer tax scheme. See text accompanying note 19 supra.

${ }^{155}$ See text accompanying notes 82-86 supra.

${ }^{156}$ I.R.C. $\S 2602(\mathrm{c})(5)(\mathrm{C})$. This would occur only if the generation-skipping transfer were itself subject to a state death tax, which seems unlikely, except perhaps in the case of some special powers of appointment. This provision may anticipate future state legislation imposing a tax on generation-skipping transfers. In any event, the credit under this provision cannot exceed the amount by which the state tax credit, as limited by the ceiling in I.R.C. $\S 2011$ (b), would have been increased if the generation-skipping transfer had been included in the deemed transferor's gross estate. See House REPORT, supra note 21 , at $54-55$.

${ }^{157}$ See I.R.C. $\$ 2602$ (c)(1). The gift tax credit, I.R.C. $\$ 2012$, is repealed for gifts made after 1976, because the gift tax is subtracted in computing the estate tax. See I.R.C. § 2012(e) added by Tax Reform Act of 1976, § 2001(a)(3); note 29 supra.

158 I.R.C. $\$ 2603(a)(1)$. The distributee is liable for the tax only to the extent of the fair market value of the property at the date of distribution. I.R.C. $\S 2603$ (a)(3). In the case of a taxable termination, the trustee is permitted to request from the Internal Revenue Service information concerning the generation-skipping transfer tax rate bracket of the deemed transferor and the extent to which the $\$ 250,000$ exclusion has already been utilized, and the trustee will not be personally liable for any shortfall in the tax caused by his reliance on the information so provided. I.R.C. $\S 2603$ (a)(2). The trustee can also obtain information from the Service concerning the valuation of property included within a generation-skipping transfer. I.R.C. $\$ 7517$, added by Tax Reform Act of 1976, § 2008(a)(1). See House RePORT, supra note 21, at 57-58 \& n.16. Regardless of these limits on the personal liability of the distributees and trustees, the property transferred is subject to a lien until the tax is paid or becomes unenforceable due to the running of the statute of limitations. I.R.C. § 2603(b); HOUSE REPORT, supra note 21, at 58. The rules concerning personal liability and liens come into play only if the tax is not paid when due. 
erty is deemed to be a taxable termination with respect to that property. ${ }^{159}$ Of course, the grantor may direct the trustee to pay the tax in all instances, but this would increase the tax base pro tanto for taxable distributions. ${ }^{160}$ In this respect the generationskipping tax resembles the estate tax but not the gift tax under which the donor bears the burden with no "grossing up." 161

Where an event triggers simultaneous taxable transfers with respect to two or more trusts, resulting in a tax computed with reference to a common deemed transferor, the tax is computed as if the aggregate of such transfers had been a single transfer and the tax imposed upon each trust is the amount that bears the same ratio to the total tax as the fair market value of each transfer bears to the total fair market value of the property transferred. ${ }^{162}$

Generally, the person liable for the tax will be required to file a return. ${ }^{163}$ If the deemed transferor is alive at the time of the transfer, the return date is the ninetieth day after the close of the trust's taxable year in which the transfer occurred. ${ }^{164}$ If the transfer occurs at or after the deemed transferor's death, the return will be due at the earlier of ninety days after the estate tax return is due (taking. applicable extensions into account) or nine months after the transfer occurs. ${ }^{165}$ Otherwise, normal estate

159 See text accompanying note 94 supra.

160 For a discussion of the tax effect of such a payment, see note 116 supra \& accompanying text. Draftsmen of generation-skipping trusts should provide for this possibility.

161 Compare I.R.C. § 2205 (estate tax) with I.R.C. \$ 2502(d) (gift tax).

162 I.R.C. $\$ 2602$ (d). The formula would be based upon the fair-market value of the trust property, in the case of a termination, and upon the value of a distribution. For example, assume that the grantor's child is a beneficiary of two trusts, with remainder over to the child's issue. Upon death of the child, assume that the values of the trusts are $\$ 3,000,000$ and $\$ 7,000,000$ respectively. The tax will be computed under chapter 13 as though there had been a single transfer of a trust valued at $\$ 10,000,000$. The resulting tax will be allocated between the two trusts on a 30-70 ratio. The effect of this rule is to spread the effect of the progressive marginal rates among the transfers involved. See House REPORT, supra note 21, at 55. Unfortunately, it is not stated how the values of any deductions are to be allocated in computing the generation-skipping tax. See id. The $\$ 250,000$ exclusion is to be allocated among the trusts in proportion to their fairmarket values in the case of simultaneous taxable events. $I d$. at 53.

${ }^{163}$ See I.R.C. $\S 2621$ (c)(1), which provides guidelines for Treasury regulations in this area. The distributee or trustee will presumably be required to file regardless of who actually pays the tax. See note 158 supra \& accompanying text. Returns are to be filed even if no generation-skipping tax is due. See House REPORT, supra note 21 , at 58-59.

164 I.R.C. $\S 2621$ (c)(I)(B)(i).

165 I.R.C. $\$ 2621$ (c)(1)(B)(ii); CONFERENCE REPORT, supra note 21 , at 617 . In addition, the trustee may be required to file information returns, without regard to the 
and gift tax procedural rules apply. ${ }^{166}$

\section{Relationship to THE INCOME Tax ${ }^{167}$}

The principles of section 691 , relating to income in respect of a decedent, are applicable to generation-skipping trusts. ${ }^{168}$ An income item or right thereto may be included in the generationskipping tax base, even though the item is neither received nor reportable for income tax purposes by the trust or distributee until after the date of the generation-skipping transfer. In such a case, assuming that the generation-skipping transfer occurs at or after the death of the deemed transferor, the net generationskipping tax attributable to that item is available as an income tax deduction for the trust or distributee required to report it as income. ${ }^{169}$.

The new carry-over basis rules of section 1023 for property acquired from a decedent apply to property subject to a generation-skipping transfer, provided again that the transfer occurs at or after the death of the deemed transferor. ${ }^{170}$ This provision enables the trust or distributee to obtain certain upward adjustments to basis. For property presently in existence,

occurrence of a taxable transfer. I.R.C. $\S 2621$ (c)(2). For an example of a situation in which such a return might be required, see note 90 supra.

${ }^{166}$ See I.R.C. \$ 2621 (a). Whether gift tax or estate tax procedures apply depends upon whether the generation-shipping transfer occurred before (gift tax rules) or at or after (estate tax rules) the deemed transferor's death. I.R.C. $\$ \$ 6166$ and $6166 \mathrm{~A}$, relating to the postponement of tax payment where the estate consists largely of an interest in a closely-held business, do not apply to the generation-shipping tax. I.R.C. § 2621(b).

${ }^{167}$ Some of the relationships of the generation-skipping tax to the estate and gift tax have already been mentioned. See notes $45,63,145 \&$ accompanying text, note 166 supra.

${ }^{168}$ I.R.C. $\S 691$ (c)(3), added by Tax Reform Act of 1976, $\$ 2006(b)(3)$.

169 I.R.C. $\$ 691$ (c)(3)(C). See Conference RePORT, supra note 21 , at 616 . The House version of the bill, H.R. 14844, 94th Cong., 2d Sess., 122 Cong. Rec. H7758 (daily ed. July 26, 1976), proposed I.R.C. \& 2614(a), which would have allowed a trust distributee required to report income under I.R.C. $\$ \$ 652$ or 662 (requiring inclusion of income received by beneficiaries of trusts distributing current income and accumulating income or distributing corpus, respectively), an income tax deduction equal to the net generation-skipping tax. See House REPORT, supra note 21, at 58. This provision was fortunately dropped in conference. Otherwise, the transfer tax would have lost its nature as a separate tax on capital already subject to income taxes.

170) I.R.C. $\S 2614$ (a). Under I.R.C. $\S 1023$, added by Tax Reform Act of 1976, $\S 2005$, the estate or heir (trust or distributee) acquires the same basis as that of the decedent. In the case of property subject to the estate tax, $\$ 10,000$ of personal effects are exempt from the rule; the minimum basis of other property is $\$ 60,000$ (or the estate tax value thereof). I.R.C. $\S 1023($ b)(3), (d). These exemptions do not apply, however, to a generation-skipping transfer. See CONFERENCE REPORT, supra note 21, at 614 . 
the basis (for the purpose of determining gain but not loss) will be stepped-up to its value as of December $31,1976 .{ }^{171}$ In addition, the adjusted basis of the property in the hands of the trust or distributee is increased (but not above its value) by that portion of the generation-skipping tax which is attributable to the appreciation element in the trust property. ${ }^{172} \mathrm{~A}$ similar adjustment is also available for trust property where the generationskipping transfer occurred prior to the death of the deemed transferor. ${ }^{173}$ The adjustment is sensible conceptually because it achieves the same result as the income tax deduction for income in respect of a decedent. ${ }^{174}$

In cases where the trust consists of stock in a closely-held corporation, the redemption rules of section 303, as revised by the Tax Reform Act of 1976, apply to the trust as if it were a separate estate. ${ }^{175}$ Section 303 will be of greatly reduced significance, however, once the impact of the carry-over basis rules is felt. ${ }^{176}$

171 In the case of marketable securities this is the actual fair market value on December 31, 1976. For other property, the increase over the basis up to the decedent's death (generation-skipping transfer) is prorated in accordance with the ratio of the number of days in the holding period prior to January 1,1977 , to the total number of days in the holding period. I.R.C. $\S 1023(\mathrm{~h})(2)$. The carryover basis provisions do not apply to income in respect of a decedent, the proceeds of life insurance, and annuity payments. I.R.C. $\$ 1023(b)(2)$. See House RePorT, supra note 21, at 36-46; Conference REPORT, supra note 21, at $611-13$.

172 I.R.C. § 2614(a); see I.R.C. §§ 1023(c) \& (f)(3).

173 I.R.C. $\$ 2614$ (a). This rule parallels a change in the basis rule with respect to inter vivos gifts in general. I.R.C. § 1015(d)(6), added by Tax Reform Act of 1976, $\$ 2005$ (c). The previous rule had been that the basis was increased (up to the fair market value at the time of the gift) by the entire gift tax paid. I.R.C. $\S 1015(\mathrm{~d})(1)(\mathrm{A})$ (1958). See House REPORT, supra note 21, at 58.

${ }^{174}$ See note 169 supra \& accompanying text. The "income" is the unrealized appreciation which will eventually become gain to the trust or distributee, and the "deduction" is the increase in basis which will reduce the amount of such income.

175 I.R.C. $\$ 303(d)$, added by Tax Reform Act of 1976, $\$ 2006(b)(4)$. For this purpose, the value of the stock is measured against the amount of the generationskipping transfer and not the entire trust or estate. See Conference Report, supra note 21 , at 616. I.R.C. $\S 303(\mathrm{~b})(2)$ (A) was amended to provide that, in order to qualify for a capital gains redemption, the value of the stock must exceed $50 \%$ of the adjusted gross estate (or the generation-skipping transfer). Tax Reform Act of 1976, \$ 2004(e)(2).

176 Under pre-1977 law, the stepped-up basis rule of I.R.C. $\$ 1014$ resulted in little or no gain on the redemption of stock. The December 31, 1976 adjustment provision, note 171 supra, will preserve this advantage for a while. Section 303 guarantees capital gains treatment for the redemption, but the now more potent minimum tax on tax preference items, I.R.C. $\$ \$ 56 \& 57$, will dilute this benefit. 


\section{Impact on Estate Planning}

\section{A. Exclusions and Deductions}

The first issue confronting estate planners is the extent to which they can reasonably avoid the new generation-skipping tax provisions. ${ }^{177}$ The most glaring escape route is the $\$ 250,000$ exclusion for generation-skipping transfers to the grantor's grandchildren. ${ }^{178}$ The exclusion creates an incentive to avoid at least one round of estate tax, without regard to the intrinsic desirability of maintaining trusts for adult children until or after their death. The fairly wealthy can be expected to continue to avail themselves of the generation-skipping trust, but the amount of aggregate assets placed in such trusts is likely to be in direct proportion to the number of children of the grantor who have children. ${ }^{179}$ It would be risky to designate the succeeding interests as "issue," however, because the exclusion will be lost unless the transferees are the grantor's grandchildren. ${ }^{180}$ The problem, previously discussed, of ascertaining what constitutes a "transfer to" the grandchildren must also be considered. ${ }^{181}$

Even if the exclusion is insufficient or unavailable, the estate planner can utilize the deemed transferor's unused unified transfer tax credit to offset the generation-skipping tax. To do so effectively, future trust interests should be created so that the deemed transferors will be persons likely to be relatively impecunious. Of course, it is difficult to accurately predict an in-

${ }^{177}$ Some observers might contend that the generation-skipping tax is unconstitutional. An unapportioned "direct" tax (which is not an income tax) is unconstitutional. See U.S. Const. art. I, § 2, cl. 3; § 8, cl. I; 9 , cl. 4; amend. XVI. The definition of a "direct" tax, however, is not entirely clear. It is likely that courts would view a tax based upon the shifting of the enjoyment of property rather than ownership as an "excise" tax rather than a "direct" tax. See Fernandez v. Weiner, 326 U.S. 340 (1945).

${ }^{178}$ See text accompanying notes $120-32$ supra.

${ }^{179}$ The exclusion is for each child of the grantor who is a deemed transferor. I.R.C. $\$ 2613(b)(6)$. Since the identity of the deemed transferor hinges on the identity of the transferees, the number of exclusions cannot be predicted with certainty when a trust for "children" is set up. This uncertainty provides some incentive to create separate trusts for each child, since the child's child is more likely to be alive at the death of his parent than at the death of the survivor among his parent and the parent's siblings. A countervailing consideration is that, in cases in which the child's child predeceases him, the $\$ 250,000$ exclusion can be lost, at least where the ultimate transferees would not be grandchildren of the grantor. This factor can be avoided by establishing a discretionary trust with respect to the grantor's children, favoring the grantor's grandchildren as a class as the remainder interest (as opposed to favoring the grantor's issue per stirpes).

180 See note 179 supra.

${ }^{181}$ See note 122 supra \& accompanying text. 
dividual's future economic situation. Because the unified transfer tax credit is only available when the transfer occurs at or after the death of the deemed transferor, this technique cannot be utilized by cutting off beneficiaries' interests at specified early ages. ${ }^{182}$

It must also be borne in mind that the generation-skipping tax excludes trusts for ancestors, parents, siblings, and spouses, without dollar limitation. ${ }^{183}$ This factor, in combination with the substantial unified transfer tax credit, will have a significant effect on the pattern of devolution of small or medium estates, especially of married persons. Couples have traditionally split the propertied spouse's estate into roughly equal marital-deduction and residual trusts. The taxable estate does not include the value of a properly qualified marital-deduction trust, ${ }^{184}$ and the residual trust would not be taxed upon the death of the surviving spouse, even though the latter would be a beneficiary of the trust. ${ }^{185}$ One of the objectives of the split-trust arrangement has been to minimize the estate tax upon the death of the second spouse. Because the marital-deduction trust must incur estate tax with respect to the second spouse, ${ }^{\mathbf{1 8 6}}$ routine practice is to make the trust large enough to qualify for the maximum marital deduction but no larger. ${ }^{187}$ Henceforth, given a unified

${ }^{182}$ See note 150 supra \& accompanying text.

${ }^{183}$ This statement follows from the definitions of a "generation-skipping trust" and of "generations" found in I.R.C. $\$ \$ 2611$ (b) \& (c). The exclusion holds true regardless of the ages of the siblings or spouse as compared to that of the grantor. See text accompanying notes 33-37 supra. A cynical person might suggest that the generation-skipping tax creates an incentive for wealthy persons to "rob the cradle." It has been proposed that property should be permitted to be transferred from one spouse to another free of tax only after the marriage has lasted five years, or the couple has had a natural-born child. See 3 Report of the Royal Commission on TAXation 127 (1966) (Canada).

184 I.R.C. §§ 2056(a),(b), \& (e). To qualify, an interest must (1) pass from the decedent to his surviving spouse, (2) be includible in the decedent's gross estate, and (3) avoid being a non-deductible terminable interest.

${ }^{185}$ See note 1 supra \& accompanying text.

${ }^{186}$ In order to prevent the marital deduction trust from being a non-deductible terminable interest, the spouse who is the sole beneficiary must possess a general power of appointment that is exercisable by him or her alone and in all events. I.R.C. $\S 2056(b)(5)$. This power of appointment causes inclusion of the trust property in the surviving spouse's gross estate under I.R.C. $\$ 2041$ (a)(2). Alternatively, qualification for the marital deduction is obtained when the corpus is payable to the spouse's estate. I.R.C. $\S 2056(\mathrm{~b})(\mathrm{I})(\mathrm{A})$.

${ }^{187}$ For a discussion of the maximum marital deduction, see note 189 infra. Formula clauses in wills and trusts achieve the intended result, usually, by creating a trust equal to the amount of the excess of the maximum marital deduction for federal estate tax purposes over the sum of bequests, etc., to the surviving spouse (which pass outside of the formula clause) that qualify for the marital deduction. See A. Casner, 
transfer tax credit that will effectively exempt $\$ 175,625$ from the tax base by $1981,{ }^{188}$ the first spouse can more easily divert assets from the marital-deduction trust into the residual trust, which is not taxed upon the death of the second spouse. Due to the size of the unified transfer tax credit, optimal utilization of the increased marital deduction under the Tax Reform Act of 1976 will create real benefits only for those with adjusted gross estates of between $\$ 350,000$ and $\$ 500,000 .{ }^{189}$

\section{B. Postponement Rules}

The postponement rules are tempting avenues for delaying and thus minimizing exposure to the generation-skipping tax.

Estate Planning 791-806 (3d ed. 1961); note 189 infra.

${ }^{188}$ For gifts made and decedents dying after 1976, the unified transfer tax credit, found in I.R.C. $\S \S 2010,2505$, added by the Tax Reform Act of 1976, $\S \S 2001$ (a)(2), $2001(b)(2)$, is $\$ 47,000$ for 1981 and subsequent years, $\$ 42,500$ for $1980, \$ 38,000$ for 1979 and $\$ 34,000$ for 1978 . The estate tax credit for decedents dying in 1977 is $\$ 30,000$; the gift tax credit for gifts made in the first half of 1977 is $\$ 6,000$ and for gifts made in the latter half of 1977 is $\$ 30,000$. A credit of $\$ 47,000$ translates into a deduction of $\$ 175,625$. The exemption of $\$ 60,000$ of I.R.C. $\$ 2052$ (1954) is repealed. Tax Reform Act of 1976, § 2001(a)(4).

${ }^{189}$ Under I.R.C. $\$ 2056(\mathrm{c})(\mathrm{I})(\mathrm{A})$, as amended by the Tax Reform Act of 1976, $\S 2002$ (a), the maximum marital deduction is equal to the greater of $\$ 250,000$ or $50 \%$ of the decedent's adjusted gross estate (gross estate less debts, expenses and losses). For estates of about $\$ 175,000$ or less no qualifying marital deduction gift need be used because the estate will not be subject to tax in any event due to the unified transfer tax credit. See note 188 supra. The next $\$ 250,000$ in assets can be given to the spouse free of tax under the expanded maximum marital deduction. If the estate's value is less than $\$ 350,000$, however, the size of an efficiently effected marital deduction gift will be smaller than that under pre-1977 law, under which the maximum marital deduction was $50 \%$ of the decedent's adjusted gross estate. See I.R.C. $\$ 2056(c)(1)$ (1954). For example, in an estate of $\$ 275,000, \$ 175,000$ would be in the residual trust, and $\$ 100,000$ would be in the marital deduction trust. If an estate's value is between $\$ 425,000$ and $\$ 500,000$, no more than $\$ 250,000$ should be left to the surviving spouse, because anything more would exceed the transfer tax credit and maximum marital deduction. For estates valued beyond the $\$ 500,000$ plateau (which is twice the "minimum" maximum marital deduction), $50 \%$ of the excess may be added to the marital deduction trust. This reflects no change, however, from prior law. A formula clause that would accord with the foregoing suggestions could be written along these lines:

If my spouse survives me, I bequeath to (him, her) an amount equal to the excess of the "tentative marital deduction bequest," described in the next sentence hereof, over the sum of amounts which qualify for the marital deduction for federal estate tax purposes which pass to such spouse outside of this clause of this instrument. The "tentative marital deduction bequest" is an amount equal to the excess of my taxable estate for federal estate tax purposes, computed without regard to the federal estate tax marital deduction, over the exemption equivalent of the maximum federal unified transfer credit available to my estate, but said amount shall not in any event exceed the maximum marital deduction allowable for federal estate tax purposes.

For discussion of another aspect of the relationship between the generation-skipping tax and the marital deduction, see notes $147-48$ supra \& accompanying text. 
The most obvious possibility (subject to the Rule Against Perpetuities) would be to create a discretionary trust for a large number of beneficiaries of the same generation. For example, consider a trust established for the benefit of the grantor's grandchildren and their spouses until the death of the survivor, with remainder to the grantor's then surviving issue. ${ }^{190}$ Alternatively, a trust for the grantor's children and their spouses, followed by interests in the grantor's parents, uncles, aunts, spouse, and siblings, would probably invoke the unusual-order-of-death postponement rule. ${ }^{191}$

Although such arrangements present significant tax avoidance opportunities to the taxpayer, countervailing considerations must be weighed. The Treasury is expressly authorized to issue regulations proscribing the use of nominal or "dummy" samegeneration beneficiaries, especially where income accumulations during their tenure can be foreseen. ${ }^{192}$ Moreover, the postponement rule can be negated by regulation in cases where each same-generation beneficiary possesses, in effect, a separate share of the trust. ${ }^{193}$ Finally, in appropriate instances, the regulations may prevent abuse of the unnatural-order-of-deaths postponement rule. ${ }^{194}$

In a similar vein, a trust can be created for the grantor's grandchildren, with remainder to a charity. Not only will this trust escape the generation-skipping tax, but the grantor may also obtain a charitable deduction against his income and trans-

${ }^{190}$ See I.R.C. $\S 2613(\mathrm{~b})(2)(\mathrm{B}) ;$ text accompanying note 82 supra.

${ }^{191}$ See note 87 supra \& accompanying text.

192 See I.R.C. $\$ 2613$ (b)(2)(B); House RePoRT, supra note 21 , at 51 \& n.5. For example, a "dummy" beneficiary might be one who is not a descendant of the grantor where other beneficiaries and remaindermen under the trust are descendants of the grantor. If, however, the trustee does not have the power to accumulate, then presumably the beneficiaries are genuine.

${ }^{193}$ See I.R.C. § 2622 . An example is a situation involving a trust for the grantor's children in which each child obtains a pro rata share of the income from the trust, and upon a child's death a pro rata portion of the corpus is distributed to (or held for) such child's successors in interest. See House RePort, supra note 21, at 51; Conference REPORT, supra note 21, at 618. The determination of the existence of separate shares will presumably accord with the analogous rules with respect to the income taxation of trusts. See Treas. Reg. $\$ 1.663(\mathrm{c})-3$ (1972).

${ }^{194}$ I.R.C. $\S 2613(\mathrm{~b})(2)(\mathrm{C})(\mathrm{i})$. These regulations would probäbly cover situations in which a higher generation beneficiary does not, or is not expected to, receive substantial benefits under the trust, or in which that beneficiary has a long life expectancy or is not himself a younger generation beneficiary (so that his death will not be a taxable termination). An example would be a trust for the grantor's aged and sickly son for life, then to the grantor's 22 year old wife, with the remainder over, assuming that the son dies first. 


\section{fer taxes. ${ }^{195}$}

Conceivably, a taxpayer may use the postponement rules or a charitable-remainder trust in conjunction with the $\$ 250,000$ exclusion. This possibility depends upon whether grandchildren must receive interests that will be includable in their gross estates in order to qualify their parent as a deemed transferor eligible for the $\$ 250,000$ exlusion. ${ }^{196}$

\section{Disclaimers}

Retroactive planning may be accomplished through the newly-enacted mechanism of section 2518 by which a beneficiary may disclaim an interest in a generation-skipping trust. ${ }^{197} \mathrm{~A}$ corpus distributee in a taxable distribution might avoid tax liability in this fashion. A disclaimer, or a series thereof, can probably eliminate a younger generation of beneficiaries entirely, thereby resulting in the elimination of the generation-skipping tax itself. ${ }^{198}$ The disclaimer provisions are somewhat ambiguous with

${ }^{195}$ See note 140 supra \& accompanying text. To qualify for income, estate and gift tax deductions, the trust must be a charitable remainder annuity trust or a charitable remainder unitrust (or a pooled income fund), with no power to invade corpus for the benefit of the non-charitable beneficiaries. I.R.C. $\$ \$ 170(f)(2)(A), 2055(e)(2), 2522(c)(2)$. Congress' allowance of multiple charitable deductions with respect to one transfer seems overly generous.

${ }^{196}$ See notes 124-25 supra \& accompanying text. The possibility of so combining the benefits of these rules is a reason for strictly construing the exclusion.

${ }^{197}$ See I.R.C. \$ 2614(c). The uniform disclaimer rules are contained in I.R.C. $\S \S 2045$ (estate tax), 2518 (gift tax), added by $\$ 2009$ (b) of the Tax Reform Act of 1976. These sections provide that a disclaimer may be effected not later than nine months after the day on which the interest is created or the beneficiary attains the age of twenty-one, by a written, irrevocable and unqualified refusal to accept an interest in property, regardless of state law on the subject. See HOUSE REPORT, supra note 21, at 65-68.

${ }^{198}$ In the case of a taxable termination, a literal reading of the statute appears to preclude the use of disclaimers to eliminate the existence of a younger generation for the purpose of determining the existence of a generation-skipping trust. Consider, for example, a trust for the benefit of the grantor's child $C$ for life, with remainder to grandchild $D$ if living, but if $D$ is not living, to the grantor's nephew $N$ or his estate. Assume that at the death of $C$, both $D$ and $N$ are living, but $D$ disclaims his interest. The statute perpetuates a generation-skipping transfer in this case because $D$ (a lower generation beneficiary) "exists" as of the moment just prior to the termination of $C$ 's interest. I.R.C. $\S \S 2611$ (a) \& (b), 2613(b)(1) \& (c)(2). Although the identity of the "transferee" has shifted from $D$ to $N$, under I.R.C. $\$ 2518$ the definition of "deemed transferor" in I.R.C. $\S 2612$ (a) does not require that the parent of the transferee is himself a younger generation beneficiary. It apparently follows that the deemed transferor of the generation-skipping transfer is whichever of $N$ 's parents is more closely related to the grantor. This approach, however, does not seem consistent with the statutory plan. See text accompanying note 102 supra. If the alternate remainder were to a charity (rather than $N$ ), a full charitable deduction would be available. Therefore, the regulations should indicate that in situations such as that described above there is no generationskipping transfer. 
respect to which events provide an opportunity to disclaim. ${ }^{199}$

\section{Separate Trusts}

One final major tax-avoidance possibility must be mentioned. It appears that a taxpayer may be able to establish separate trusts for different generations: trust $A$ for the benefit of the grantor's children for their joint lives, with remainder to the grantor's great-grandchildren; and trust $B$ for the benefit of the grantor's grandchildren, also with remainder to the grantor's great-grandchildren. The advantage of the split-trust is that there will be one taxable transfer when the survivor of the children dies (trust $A$ ) and one when the grandchildren have died (trust $B$ ). If there had been a single trust for the children, then to the grandchildren, then to the great-grandchildren, two taxable transfers would have occurred with respect to the value of the single large trust before its benefits reached the greatgrandchildren. Either trust may lie dormant for a period of time accumulating income which will increase the ultimate generation-skipping tax base. This prospect may be avoided by providing for liberal powers of corpus invasion for the active trust. Although an arrangement of this type might appear to be economically practical only for the very wealthy, in fact, it could be utilized by a broad range of grantors.

The possibility of a split-trust arrangement is not mentioned in the statute or committee reports. Nor is it literally covered by the provision dealing with "trust equivalents."200 Nevertheless, the Treasury should attempt to close this loophole by issuing regulations purporting to combine separate trusts. Section 2622 confers specific authority upon the Treasury to issue such regulations under chapter 13 as "may be necessary or appropriate to

${ }^{199}$ The Conference Report, supra note 21 , at 617 , states that the event triggering the disclaimer period is the generation-skipping transfer. This interpretation seems contrary to the language of I.R.C. $\S 2518$, which states that the nine month period is triggered by the transfer "creating" the interest to be disclaimed, which could be read to mean the date of the creation of the trust. In any event, there appears to be nothing in $\$ 2518$ to prevent a beneficiary from disclaiming an interest before the transfer, shortly after the creation of the trust, or before reaching his twenty-first birthday.

${ }^{200}$ See notes 66-68 supra \& accompanying text. Section $2611(\mathrm{~d})(1)$ states that a trust equivalent "means any arrangement which, although not a trust, has substantially the same effect as a generation-skipping trust." (Emphasis supplied). To be sure, an arrangement consisting of two or more trusts is not "a" trust and therefore is not literally within the italicized phrase. However, in the absence of any reference to this problem in the legislative history, it is difficult to infer that $\S 2611$ (d) was intended to reach multiple trust arrangements. 
carry out the purposes" of the generation-skipping provisions. ${ }^{201}$ Such "legislative," as opposed to "interpretative," regulations would have the force of law if reasonable and within the scope of the granted authority. ${ }^{202}$ Regulations directed at an obvious loophole, though not expressly sanctioned, would appear to come within the ambit of section 2622. ${ }^{203}$ Moreover, separate trusts containing broad powers of invasion are closely analogous to annuity-death benefit combinations covered by the "trust equivalent" provision. ${ }^{204}$ Because the results should not differ for the very wealthy who can afford to leave the corpus of each trust intact, a reasonable basis exists for extending the analogy to trusts without liberal invasion powers. Finally, regulations along the lines suggested would find substantive support in the case law dealing with reciprocal transfers. ${ }^{205}$ The regulations should apply at a minimum to separate trusts created under the same instrument, and to trusts created under multiple instruments taking effect at the same time. ${ }^{206}$ Other situations could be dealt with on a case-by-case basis. ${ }^{207}$

\section{Effective Dates}

The new provisions are applicable only to generation-skipping transfers made after April 30, 1976. ${ }^{208}$ Therefore, trusts which were irrevocable on that date are "grandfathered."209

201 I.R.C. $\$ 2622$.

${ }^{202}$ See Commissioner v. South Texas Lumber Co., 333 U.S. 496, 501 (1948). See also Joseph Weidenhoff, Inc., 32 T.C. 1222, 1241 (1959), acq. in result, 1960-2 C.B. 7.

${ }^{203} \mathrm{Cf}$. House RePORT, supra note 21 , at $53 \mathrm{n} .8$ (stating that trusts created by a donor's spouse are aggregated with those of a donor for purposes of the exclusion for any of their children, although no mention of this is made in I.R.C. $\$ 2613(b)(6)$ ).

${ }^{204}$ See I.R.C. $\$ 2611(\mathrm{~d})(2)$.

${ }^{205}$ Cf. United States v. Estate of Grace, 395 U.S. 316 (1969) (construing Int. Rev. Code of 1939, $\S 811$ (c)(1)(B), 63 Stat. 894 (now I.R.C. $\S 2036$ )). Although this decision rested primarily on the objective manner in which the pieces fit together, in less obvious cases the same result could be obtained under a finding of tax-avoidance intent. See 60 Mich. L. REv. 631 (1962). Although Estate of Grace dealt with the "transfer" requirement of the predecessor of I.R.C. $\$ \$ 2036-38$ in a two-grantor context, its principle is applicable to the one-grantor, two-trusts situation, and it undermines the separatecontract rule of Fidelity-Philadelphia Trust Co. v. Smith, 356 U.S. 274 (1958) (pre-1954 law).

206 The time in question is the settlor's death. The regulations could be phrased to encompass testamentary trusts and any trust whose value is includible in the settlor's gross estate under I.R.C. $\$ \$ 2035-38$.

207 Any approach should take account of: (1) identity of the settlor(s); (2) size of the trusts; (3) the class of beneficiaries; and (4) a tax-avoidance motive. See note 203 supra.

208 Tax Reform Act of 1976, § 2006(c)(1).

209 However, if transfer or addition is made to a pre-May 1, 1976, irrevocable trust, the generation-skipping rules will apply pro tanto. Tax Reform Act of 1976, 
Moreover, and somewhat incredibly, a donee of a special power of appointment created by an instrument which was irrevocable as of the April 30, 1976 cut-off date can create future generation-skipping arrangements that will also avoid the generationskipping tax. ${ }^{210}$

The transitional rules also treat trusts under amendable wills and revocable trust instruments existing on April 30, 1976 generously. They are not considered to be generation-skipping trusts if the grantor dies before $1982,{ }^{211}$ or even later in cases of incompetency. ${ }^{212}$ Therefore, subject to a note of caution, ${ }^{213}$ a taxpayer need not revise an amendable will or revocable trust until December 31, 1981 draws near. Moreover, these wills and trusts can be amended and altered in the meantime, as long as generation-skipping arrangements are not created or increased. ${ }^{214}$ Again, the definition of such a creation or increase is not altogether clear. ${ }^{215}$ A final question requiring clarification is

$\S 2006(\mathrm{c})(2)(\mathrm{A})$. See House Report, supra note 21 , at 59 . Although it is not clear whether the amount to be subject to tax is the amount of the corpus transferred to the trust after April 30, 1976, or the pro rata portion of the trust on the date of transfer attributable to such contributions, the latter seems proper.

${ }^{210}$ This assumes that the exercise of this special. power of appointment would not be taxable under I.R.C. $\$ 2041$ (a)(3) or $\$ 2514$ (d) (applying to the exercise of a power of appointment by creating another such power). CONFERENCE REPORT, supra note 21, at 621. This result is surely too generous, because the donee will not be compelled to create a generation-skipping trust.

211 Tax Reform Act of 1976, $\$ 2006(c)(2)(B)$.

$212 \mathrm{Id}$. If the decedent was unable to change the disposition of his property on April 30, 1976 because of mental disability, the grace period for amendment is two years after he first regains his competence.

${ }^{213}$ The caveat alluded to is that the unrevised trust or will is subject to the tax if the decedent was competent on April 30, 1976, becomes disabled after that date, and dies after 1981 .

${ }^{214}$ Tax Reform Act of 1976, § 2006(c)(2)(B).

215 See Conference Report, supra note 21 , at 620 . If interests for beneficiaries of a generation younger than the grantor's which had not previously been provided for are created (or powers of appointment are added which can be exercised to the same effect) by amending a will or trust after April 30,1976, the trust will become subject to the new provisions. Adding new members to a generational class, or changing members within such a class, would not constitute an increase. Assuming a generation-skipping trust is to be funded by the residue of the grantor's estate, it would appear that the deletion of legacies would result in a tax-invoking increase. Commentators have suggested that the substitution of a charitable beneficiary for an individual would also run afoul of the transitional rule. See McCoy, Pearl \& Abramson, The New Estate and Gift Tax Law-An Initial View, 1976-3 EsT., GrFTs \& TR. J. 4, 10. A contemplated change in a marital deduction formula bequest, perhaps to conform to the 1976 changes, see note 189 supra, which could reduce the amount of the bequest, should be approached with caution. Although increasing the duration of a younger generational interest would negate the grandfather provision, the result if other younger generational interests are shortened pro tanto is especially difficult to predict. The grandfather rule applies only 
whether additional cash or property can be transferred to revocable trusts after April 30, 1976. There is reason to believe that such actions would not negate the transitional rules. ${ }^{216}$

\section{Conclusion}

Chapter 13 of the Tax Reform Act of 1976 is designed to eliminate an existing tax incentive for creating generationskipping arrangements by approximating the tax that would have been imposed if the property had passed outright. The tax should not be viewed as a penalty on generation-skipping arrangements. Rather, the estate planner and his client should consider the merits of generation-skipping arrangements primarily on the basis of family, management, income tax and disposition considerations. In addition, considering the limited scope of the new rules with respect to spouses, parents, and children of the grantor, it is not likely that the institution of the trust will wither away because of the generation-skipping tax. Nevertheless, the estate advisor will want to minimize or delay exposure to the generation-skipping tax to the extent compatible with the client's plan of property devolution.

Despite precipitous enactment, serious conceptual flaws, avoidable ambiguities, and unnecessary complexities, the new statutory provisions are not as formidable or as defective as they might have been, nor do they appear to contain many unintended loopholes. Many of the more common trust arrangements will remain relatively unscathed, and will continue to be used for purposes other than tax avoidance. The appearance of regulations, and even perhaps legislative proposals from the new administration, are awaited with keen interest.

to amendments (including codicils); it would not protect new instruments, even if substantially identical to pre-May 1976 instruments.

216 Perhaps, the augmented portion of the trust would be regarded as not "in existence" within $\S 2006(c)(2)(B)$, and, hence, not "grandfathered." Yet this same section refers only to "amendments," whereas \$2006(c)(2)(A), dealing with irrevocable trusts, refers to "additions." Therefore, the "creation or increase of generation-skipping arrangements" restriction pertaining to revocable trusts would probably not apply to additions. Moreover, a testamentary trust, or pour-overs to a revocable trust, can be augmented without risk by reason of the grantor's becoming more wealthy or otherwise altering his property-holding arrangements. Therefore, additions to revocable trusts should be permitted. See note 215 supra. 